\title{
Bacterial community dominance of particle-attached bacteria in lakes of the Mackenzie River Delta: transparent exopolymer particle contribution
}

\author{
C. Adam Chateauvert ${ }^{1, *}$, Lance F. W. Lesack ${ }^{1,2}$, Max L. Bothwell ${ }^{3}$ \\ ${ }^{1}$ Department of Geography, and ${ }^{2}$ Department of Biological Sciences, Simon Fraser University, Burnaby, British Columbia \\ V5A 1S6, Canada \\ ${ }^{3}$ Environment Canada, Pacific Biological Station, Nanaimo, British Columbia V9R 6N7, Canada
}

\begin{abstract}
Arctic floodplain lakes of the Mackenzie River Delta receive large inputs of dissolved organic matter (DOM) and suspended particulates from allochthonous and autochthonous sources that may drive in situ formation of transparent exopolymer particles (TEP), and represent a complex combination of substrates for aquatic bacteria. During the open-water period of 2006, we tracked abundances of free-living bacteria versus those attached to TEP and to other non-TEP particles in 3 Delta lakes representing gradients of declining river-to-lake connection times, increasing levels of dissolved organic carbon (DOC), and declining total suspended solids (TSS). Total suspended bacteria (= free-living + TEP-attached + other-attached bacteria) were high in all lakes $\left(\sim 10^{6}\right.$ to $10^{7}$ cells ml $\left.{ }^{-1}\right)$ compared to tundra lakes, and most cells were particle-attached, despite the high DOC concentrations. Free-living bacteria were best related to DOC concentrations, but represented only $14 \%$ of total suspended bacteria. TEP-attached bacteria were best related to TEP mass, but represented only $9.6 \%$ of total suspended bacteria. Other-attached bacteria were best related to chromophoric DOM and TSS levels, and represented $76.5 \%$ of total suspended bacteria. Bacterial densities on TEP particles increased as TEP mass declined from lakes with strong river influence to the lakes with higher autochthonous DOC. However, bacterial density on non-TEP particles declined over the same gradient as the abundance of their substrate declined. These opposing gradients in bacterial density on particles of differing origin, combined with the high abundances of other-attached bacteria, suggest that TEP colonization is driven by the mass of particles available for colonization by free-living cells within the lakes, whereas non-TEP particles may mostly enter the lake waters pre-colonized with bacteria from terrestrial or benthic sources.
\end{abstract}

KEY WORDS: Particle-attached bacteria - Transparent exopolymer particles (TEP) · Arctic floodplain lakes · Arctic rivers · Carbon cycling · Allochthonous carbon · Particle colonization

\section{INTRODUCTION}

Aquatic microbes inhabit a complex, heterogeneous environment of chemical gradients and particulate structure (Azam 1998, Azam \& Malfatti 2007). Particulate organic matter (POM) is colonized in varying degrees by bacteria and protists, resulting in hotspots of microbial activity compared to the surrounding water (Caron et al. 1986, Simon et al. 2002). This presumably occurs because particles are a concentrated source of organic compounds compared to bulk water, and this promotes growth of microbes that are particle specialists (Delong et al. 1993, Lemarchand et al. 2006). An important advance has 
been the discovery of new classes of particles, such as carbon-rich, transparent exopolymer particles (TEP) (Alldredge et al. 1993), protein-containing, Coomassiestained particles (CSP) (Long \& Azam 1996), and detritus-rich, DAPI yellow particles (DYP) (Mostajir et al. 1995, Brachvogel et al. 2001, Carrias et al. 2002), which likely differ in nutritional content, but represent potential hotspots for the microbial community. Chin et al. (1998) showed that polymers of dissolved organic matter (DOM) spontaneously assemble into gels and that TEP is important as a macrogel capable of sedimentation. Verdugo et al. (2004) estimated from prior marine studies that $10 \%$ of surface DOM may form gel particles. Because of TEP's transparent nature, bacteria colonized on TEP may historically have been enumerated as free-living bacteria, resulting in overestimates of that portion of the bacterial community and underestimates of the particleassociated community (Simon et al. 2002). Moreover, because assembly of TEP occurs abiotically, whereas its precursors have biotic origin, there is the potential that some DOM may bypass the microbial loop by conversion to TEP followed by direct consumption by higher trophic levels or sedimentation.

At present, little is known of how TEP formation and colonization in inland waters may differ from marine environments, particularly in systems with complex mixtures of DOM. An important general class among world lakes which remains poorly understood is that of lakes associated with circumpolar river deltas (Lesack \& Marsh 2007). Such lakes are abundant (Emmerton et al. 2007), and because of their high levels of primary productivity and biodiversity, they have been characterized as 'out of place for their latitude' (Squires et al. 2009, p. 870). Recent work in the Mackenzie Delta has also shown that these lakes are DOM-rich and support high levels of bacterial production (Spears \& Lesack 2006, Tank 2009) and microbial diversity (Galand et al. 2006). Lakes in this delta contain a diverse range of DOM concentrations and compositions that are determined by lake position (Chateauvert 2008, Tank 2009, Gareis et al. 2010) along gradients of river-to-lake connectivity (Lesack \& Marsh 2010) that drive water renewal rates in the lakes (short connection time $=$ slower renewal ${ }_{i}$ long connection time $=$ faster renewal). Total supply of DOM typically increases with declining river connection times because non-chromophoric DOM is derived from the abundant macrophyte communities in these lakes, whereas chromophoric DOM (CDOM) typically decreases along this gradient because it is mainly delivered via river water during flooding events (Tank et al. 2011). Despite the potential importance of DOM and the microbial foodweb in this vast system of lakes, and in other arctic deltas and river floodplains worldwide, we are not aware of any prior work in systems like this to assess the potential importance of DOMderived TEP particles as bacterial colonization sites or the possible implications of such DOM transformation and colonization for carbon processing.

In a separate paper (Chateauvert et al. 2012), we assessed the abundance and patterns of TEP in 3 Mackenzie Delta lakes, representing a gradient of river-to-lake connection times. In the present study, we partitioned the suspended bacterial communities of these same lakes into free-living, TEP-attached, and other-attached components, and examined how these 3 community types varied with concentrations of DOM, TEP, particulate organic carbon (POC), and total suspended solids (TSS). We assess the hypothesis that TEP-attached bacteria will represent a significant portion of total suspended bacteria in delta lakes because their high DOM levels should yield abundant TEP particles, and such bacteria will be most abundant and the largest portion of the suspended bacterial community in lakes with short river connection times, where autotrophic production levels are highest and TSS levels are lowest.

\section{MATERIALS AND METHODS}

\section{Study area}

The Mackenzie River is an important representative of large north-flowing rivers in the circumpolar Arctic, and the Mackenzie Delta is located where the Mackenzie River discharges into the Beaufort Sea $\left(68-69^{\circ} \mathrm{N}, 134-137^{\circ} \mathrm{W}\right.$; Lesack \& Marsh 2010). Within this extensive $13000 \mathrm{~km}^{2}$ delta, there are $>45000$ lakes (Emmerton et al. 2007). Mean depths range from about 0.5 to $4.5 \mathrm{~m}$, and are dependent on time of year, whether the year is wet or dry locally, and whether delta water levels are higher or lower than average (Lesack \& Marsh 2010). The open-water period in the central delta is from June to November. Peak annual water levels in the river are partially controlled by the amount of water contained within the winter snowpack, but more commonly they are strongly controlled by ice breakup effects (Andres \& Doyle 1984, Prowse 1986). Delta lakes are perched at a range of elevations above Mackenzie channels (Marsh \& Hey 1989) that govern river-to-lake connection times. During such connection, lakes are replenished in varying degrees with river water, nutrients, DOM, and sediments (Marsh \& Lesack 1996, Lesack 
\& Marsh 2010). The lakes have been classified (Marsh \& Hey 1989) as in Mackay (1963). No-closure lakes (see Fig. 2 in Emmerton et al. 2007) remain in connection with river channels for the entire summer. Lowclosure lakes are flooded each spring but are cut off from the river for some portion of the summer. Highclosure lakes are not necessarily flooded every spring and never during the summer.

Three representative and well-studied lakes were chosen for the present study. Lake 129 is no-closure class, with an area of $38 \mathrm{ha}$, mean depth of $1.3 \mathrm{~m}$, and continuous river connection. Lake 56 is high-closure class, with an area of 3.1 ha, mean depth of $1.1 \mathrm{~m}$, and average river connection of $9.3 \mathrm{~d} \mathrm{yr}^{-1}$ (connected for $11 \mathrm{~d}$ in 2006). Lake 520 is high-closure class, with an area of $0.2 \mathrm{ha}$, mean depth of $2.2 \mathrm{~m}$, and average river connection of $6.5 \mathrm{~d} \mathrm{yr}^{-1}$ (connected for $10 \mathrm{~d}$ in 2006). Lakes 56 and 520 do not have substantially different river connection times, but Lake 520 is a deeper thermokarst lake (an important subclass; Tank et al. 2009a) that intermittently receives modest inputs of dissolved organic carbon (DOC) from melting permafrost (Tank et al. 2011). The macrophyte communities in these lakes are a function of longterm average water levels (see Chateauvert et al. 2012 for further details). Locations and further information on these lakes are in Fig. 1 and Table 1 of Lesack \& Marsh (2010).

\section{Sample collection}

During the summer of 2006 (early June to late August), water samples were obtained with a tube sampler, integrated over depths up to $1.5 \mathrm{~m}$ from the lake surface (less if lake $<1.5 \mathrm{~m}$ deep). Samples were taken from the same location in each lake at weekly intervals during 2006. Mackenzie Delta lakes are well mixed during the open-water season and these point samples were taken as representative values of the chemical and biological measurements made. Samples were stored in 11 high-density-polyethylene (HDPE) bottles and placed on ice in a cooler for up to $2 \mathrm{~h}$. Samples were processed immediately upon return to the laboratory.

\section{Chl a, TSS, POC, DOC, CDOM, and dissolved carbohydrates}

Chlorophyll a ( $\mathrm{chl}$ a) was measured via vacuumfiltering of lake water at no more than $175 \mathrm{~mm} \mathrm{Hg}$ through Whatman GF/C filters. The filters were frozen at $-20^{\circ} \mathrm{C}$ until subsequent analysis. Extraction of chl a was performed in $90 \%$ ethanol following Nusch (1980), and allowed to extract for $24 \mathrm{~h}$ at $4^{\circ} \mathrm{C}$. $\mathrm{Chl} a$ was then determined fluorometrically (Welschmeyer 1994).

TSS ( $\mathrm{mg} \mathrm{l}^{-1}$ ) was measured gravimetrically by filtering lake water through combusted, pre-weighed GF/C filters and drying to stable weight (Wetzel \& Likens 2000). These filters were then combusted at $550^{\circ} \mathrm{C}$ for $9 \mathrm{~h}$ (time to stable weight) before being re-weighed. The filter's combusted weight was subtracted from its dry weight to obtain POM, then multiplied by $0.47 \pm 0.01$ (Dean 1974) to estimate POC $\left(\mathrm{mg} \mathrm{l}^{-1}\right)$.

DOC was measured on lake water filtered through pre-rinsed Whatman GF/F filters. Filtered samples were stored at $4^{\circ} \mathrm{C}$ for up to 4 mo in new, pre-washed HDPE bottles until analysis (Tank et al. 2011). DOC was analyzed (Gareis et al. 2010) as non-purgeable organic carbon, based on the high-temperature catalytic oxidation method using a Shimadzu Total Organic Carbon Analyzer (TOC- $\left.\mathrm{V}_{\mathrm{CPH}}\right)$.

CDOM was measured in lake water filtered through a $0.22 \mu \mathrm{m}$ Durapore (PVDF) membrane filter. Samples were stored in new, pre-washed HDPE bottles at $4^{\circ} \mathrm{C}$ for 2 to $4 \mathrm{wk}$ until analysis (Tank et al. 2011). Spectrophotometric absorbance at $330 \mathrm{~nm}$ in a $5 \mathrm{~cm}$ path length, quartz cuvette was used as a relative measure of CDOM in the water (Kirk 1994, Whitehead et al. 2000).

Total dissolved monosaccharides (mono) was measured on GF/F-filtered lake water via the TPTZ (2,4,6-tripyridyl-s-triazine) method (Myklestad et al. 1997). Total dissolved carbohydrates (TDCHO) was measured via the same method, after a hydrolysis treatment with $\mathrm{HCl}$ to a final concentration of $0.09 \mathrm{~N}$ and incubation in sealed glass ampoules at $150^{\circ} \mathrm{C}$ for $1 \mathrm{~h}$. Total dissolved polysaccharides (poly) was calculated as the difference between TDCHO and total dissolved monosaccharides.

\section{TEP analysis}

Slide preparation

Semi-permanent slides were prepared in duplicate based on the method of Alldredge et al. (1993) with few modifications. Samples (1 to $4 \mathrm{ml}$ ) were filtered through $25 \mathrm{~mm}$ diameter, $0.4 \mu \mathrm{m}$ polycarbonate membrane filters at a constant filter pressure of no more than $150 \mathrm{~mm} \mathrm{Hg}$. Samples were stained with $0.5 \mathrm{ml}$ of $0.2 \mu \mathrm{m}$-filtered Alcian blue. The $0.03 \%$ Alcian blue in 
$0.06 \%$ acetic acid was drawn through the filter immediately. The filter-transfer-freeze method (Hewes \& Holm-Hansen 1983) was used to transfer filtered material to a glass slide, and all transfers were done by the same analyst. A loop of gel $\left(0.035 \mathrm{~g} \mathrm{ml}^{-1}\right.$ gelatine, $25 \%$ glycerine in distilled water) was placed over the filtered material while still frozen and left to solidify. Prepared slides were stored at $-20^{\circ} \mathrm{C}$ in sealed bags. Testing with this method showed that the transfer efficiency for free-living bacteria was generally $>90 \%$ (Chateauvert 2008). Because TEP particles are larger than bacteria, transfer efficiency for TEP should be even higher. To be conservative, we did not attempt to correct abundances of TEP or bacteria.

\section{TEP enumeration and calculation of size distributions}

A Moticam ${ }^{\mathrm{TM}} 1300$ color camera connected to a computer was used to capture digital images of 10 fields per slide at $250 \times$ magnification on a Leitz Aristoplan microscope. Using Motic Images Advanced 3.0 ${ }^{\mathrm{TM}}$ image analysis software, individual TEP were manually delineated to obtain the cross-sectional area of TEP particles. From the cross-sectional area of TEP particles, their equivalent spherical diameter (ESD) and volume (ESV) were calculated in order to place them into size categories and to calculate a volume-based concentration (i.e. TEP-v = ppm-v) and size distribution.

The size distribution of TEP is described by the power law:

$$
\frac{\mathrm{d} N}{\mathrm{~d}\left(d_{p}\right)}=k\left(d_{p}\right)^{b}
$$

where $\mathrm{d} N$ is the number of particles in size interval $\mathrm{d}\left(d_{p}\right)$ (interval described by mean maximal ESD) and $k$ and $b$ are constants, where $b$ describes the shape of the size distribution.

\section{TEP carbon}

The carbon content of a given TEP particle was estimated using the equation of Mari (1999):

$$
\mathrm{TEP}_{\text {carbon }}=0.25 \times 10^{-6} R^{2.55}
$$

where $\mathrm{TEP}_{\text {carbon }}$ is in $\mu \mathrm{g} \mathrm{C}$ and $R$ is the equivalent spherical radius $(\mu \mathrm{m})$. TEP carbon concentration (TEP-C) was then obtained via summing the size distribution of particles multiplied by their sizedependent C content (Mari 1999; more details in Chateauvert 2008).

\section{Partitioning of the bacterial community}

The model for the bacterial community is:

$$
\begin{gathered}
\text { Total suspended } \\
\text { bacteria }
\end{gathered}=\begin{aligned}
& \text { Free-living bacteria }+ \\
& \text { TEP-attached bacteria }+ \\
& \text { Other-attached bacteria }
\end{aligned}
$$

where free-living bacteria are not attached to any particle type, TEP-attached bacteria include all bacteria associated with TEP, and other-attached bacteria represent what is not included in the previous 2 components. Other-attached bacteria encompasses bacteria attached to detritus or any non-TEP organic particle, bacteria attached to inorganic particles, and any TEP encased bacteria that could not be enumerated due to difficulties focusing through the particle. Total suspended bacteria, free-living bacteria, and TEP-attached bacteria were counted directly, whereas other-attached bacteria were inferred by difference from the model. Mean abundances are reported $\pm 1 \mathrm{SD}$.

\section{TEP-attached and free-living bacteria}

To assess the number of TEP-attached and freeliving bacteria, duplicate slides were prepared using the double staining method from Alldredge et al. (1993). Samples were stained with DAPI (0.25 $\mu \mathrm{g}$ $\mathrm{ml}^{-1}$ ) for $10 \mathrm{~min}$ before being filtered onto $0.2 \mu \mathrm{m}$ polycarbonate membrane filters, at a constant pressure below $150 \mathrm{~mm} \mathrm{Hg}$. Alcian blue was added $(0.5 \mathrm{ml})$ and drawn through immediately. Filtered material was transferred to a glass slide via the filtertransfer-freeze method (Hewes \& Holm-Hansen 1983), covered with a loop of gel $\left(0.035 \mathrm{~g} \mathrm{ml}^{-1}\right.$ gelatine, $25 \%$ glycerine in distilled water), and stored at $-20^{\circ} \mathrm{C}$ in sealed bags until enumeration.

TEP-attached and free-living bacteria were enumerated at $1000 \times$ magnification (oil objective Leitz PL Apo) on a Leitz Aristoplan epifluorescence microscope (100-W HBO mercury bulb, G340-380 excitation, RKP 400 dichromatic mirror, LP430 suppression filter). By switching from bright field to epifluorescence, free-living bacteria could be distinguished from TEP-attached bacteria. Bacteria embedded in TEP were counted by focusing through the particles, but variability in the transparency of the TEP made this difficult to do. Thus, our enumerations of TEPattached bacteria may underestimate actual abundances. For TEP particles that were completely transparent, free-living bacteria caught between the filter and particle were counted as attached bacteria. This 
error was always below $10 \%$ (maximum) and was not accounted for in calculated abundances. Free-living bacteria were counted in 10 fields. TEP-attached bacteria were counted on 20 different particles covering the size ranges present. TEP-attached bacteria abundances were calculated using the relationship between the density of bacteria attached to differing TEP particle sizes and the size distribution of TEP particles.

Total suspended bacteria

Total suspended bacteria, based on samples of bulk water with no pre-filtration, were preserved in $1 \%$ glutaraldehyde, and stored in the dark at $4{ }^{\circ} \mathrm{C}$ until slide preparation. Replicate slides were prepared based on the methods of Porter \& Feig (1980) and Yoon \& Rosson (1990). A surfactant (Tween 80) was added to a final concentration of $\sim 1 \%$, vortexed, and allowed to penetrate aggregates for at least $2 \mathrm{~h}$ before being sonicated below $10 \mathrm{~W}$ for $30 \mathrm{~s}$ (Yoon \& Rosson 1990). DAPI was then added to a final concentration of $10 \mathrm{\mu g} \mathrm{ml}^{-1}$ and let stand for at least $10 \mathrm{~min}$. Sample aliquots (1 to $2 \mathrm{ml}$ ) were filtered on to phospho-buffered saline (PBS)-conditioned $0.2 \mu \mathrm{m}$ nucleopore filters, at a filter pressure of $178 \mathrm{~mm} \mathrm{Hg}$, followed by a rinsing with PBS. Filtered bacteria were transferred to a glass slide using the filter-transfer-freeze method (Hewes \& Holm-Hansen 1983) and covered with a loop of hot gel. Enumeration of bacteria was performed at 1000× magnification on a Leitz Aristoplan epifluorescence microscope. Bacteria were counted in 10 fields on each slide.

\section{Data analysis}

To test for differences in bacterial abundances among lakes and for a seasonal time effect within lakes, a randomized block design was performed using lake as a random (block) effect and date as a fixed effect. The same analysis was used to test for differences in bacterial densities on TEP particles of different size class as defined by mean ESD. These analyses gave the same result as a repeated-measures ANOVA. Relationships between relevant variables were assessed by linear regression of $x$ and $y$ variables. Strength of the relationships was reported via coefficients of determination $\left(\mathrm{r}^{2}\right)$ and significance was tested using ANOVA. All statistical analyses were performed in JMP 7 software.

\section{RESULTS}

\section{Ambient DOM and particle abundance}

DOM and TSS patterns have been well studied in prior work on the Mackenzie Delta (Squires \& Lesack 2003, Gareis et al. 2010) and in the 3 study lakes of the present investigation (Spears \& Lesack 2006, Tank et al. 2011). Temporal patterns of DOM, TSS, and POC (Fig. 1) during the present investigation are similar to patterns in prior work. Concentrations of CDOM, TSS, and POC declined substantially over the summer after the lakes were inundated with river water during the spring river breakup. DOC concentrations were generally high over the open-water period (in the range of 8 to $10 \mathrm{mg} \mathrm{l}^{-1}$ ) in all 3 lakes. DOC concentrations in Lake 129 declined modestly over time, whereas Lake 56 remained relatively steady and Lake 520 increased modestly. By contrast, CDOM levels declined strongly in all 3 lakes over the same period. DOC concentrations in Lake 56 were somewhat higher than expected, likely as a result of higher than average river levels in 2006 during the time of peak flooding. TSS concentrations were highest (note log scale on $y$-axis of Fig. 1C), and had the highest content of inorganic particles (as inferred from concurrent POC concentrations) at the time of peak flooding, as expected. The suspended particle pool was generally richer in POC (Fig. $1 \mathrm{C}$ versus Fig. 1D) after the initial decline in TSS.

In a separate paper on the same 3 lakes, Chateauvert et al. (2012) have shown that contrary to expectations, volumetric TEP abundances were highest immediately after the flood, when autochthonous autotrophic production was at a seasonal low and CDOM was at a seasonal high. Volumetric abundances of TEP varied seasonally by $>2$ orders of magnitude, declining from $296 \mathrm{ppm}$ immediately after flood-water replenishment in the lakes (early June) to $5 \mathrm{ppm}$ in late August, with TEP-C mass concentrations following a similar pattern from 3.24 to $0.17 \mu \mathrm{g}$ $\mathrm{C} \mathrm{ml}^{-1}$ (see Fig. 2 of Chateauvert et al. 2012). Moreover, the lake (129) with the strongest riverine influence and lowest levels of autochthonous autotrophic production had the highest mean TEP-C concentrations among the lakes.

\section{Partitioning of the bacterial community}

Total suspended bacteria

Enumerated abundances of total suspended bacteria ranged from $30.2 \times 10^{5}$ to $167 \times 10^{5}$ cells ml $^{-1}$, with 


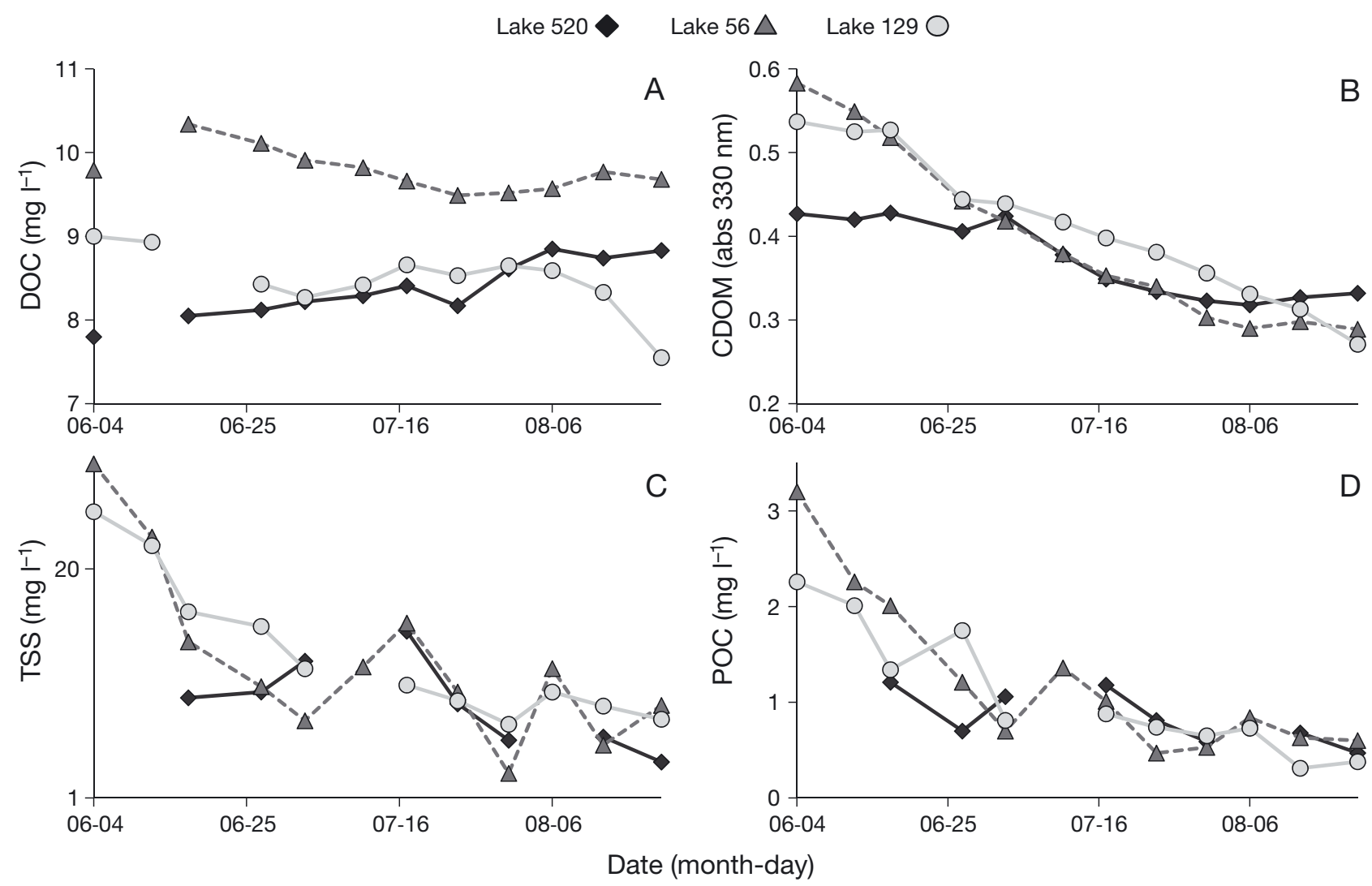

Fig. 1. Seasonal patterns of (A) dissolved organic carbon (DOC), (B) chromophoric dissolved organic matter (CDOM), (C) total suspended solids (TSS), and (D) particulate organic carbon (POC) in Lakes 520, 56, and 129 during the open-water period in 2006. Note the logarithmic scale on the $y$-axis of (C). abs $330 \mathrm{~nm}$ : spectrophotometric absorbance at $330 \mathrm{~nm}$

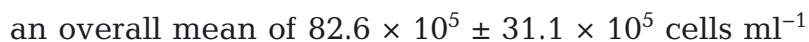
for the 3 lakes (Table 1, Fig. 2 \& 3). In Lake 129, abundance was initially high and stabilized near the mean as the summer proceeded. In Lake 56, there was no clear abundance pattern, whereas abundances in Lake 520 declined steadily over the summer. Differences in abundance over time were marginally significant $(F=2.20, \mathrm{p}=0.086$, $\mathrm{df}=8)$, as were differences among the lakes $(F=3.16, \mathrm{p}=0.070$, df $=$ 2) (randomized block ANOVA; Table 1). Considering all lakes together, abundance of total suspended bacteria was directly related (Table 2) to TEP abundance (TEP-v), TEP-C, TSS, and CDOM. In Lake 129, total suspended bacteria was inversely related to polysaccharides and carbohydrates. In Lake 520, total suspended bacteria was directly related to CDOM, POC, TEP-C, and TEP, but inversely related to DOC, polysaccharides, and chl a.

Plots containing statistically significant relationships (Table 2) between bacterial abundance and environmental variables are shown separately for each of TEP-attached, free-living and other-attached bacteria (Figs. 4 to 6). Because the relationships be- tween abundance of total suspended bacteria and environmental variables are very similar to those of other-attached bacteria, only the plots for otherattached bacteria (Fig. 6) are shown. Moreover, relationships with TEP-v are not shown, because TEP-C is either equally well or more strongly related to bacterial abundance than TEP-v in all cases (Table 2). In principle, TEP-C should also be a better measure of overall TEP mass because it accounts for the fractal relationship between volume-specific carbon content versus TEP particle size (Mari 1999).

\section{TEP-attached bacteria}

Mean enumerated abundances of TEP-attached bacteria ranged from $1.57 \times 10^{5}$ to $15.0 \times 10^{5}$ cells $\mathrm{ml}^{-1}$, and were the least abundant $\left(7.25 \times 10^{5} \pm 3.60 \times\right.$ $10^{5}$ cells $\mathrm{ml}^{-1}$ ) among the bacterial fractions in the 3 lakes (Table 1). Differences in abundance over time and among the lakes (Fig. 2A) were not statistically significant (randomized block ANOVA; Table 1), though abundances in Lake 520 qualitatively seemed 
Table 1. Descriptive statistics for bacterial abundances in each community component for Lakes 129, 56, 520, and all lakes combined. Includes randomized block ANOVA results for potential time effect and lake effect on observed abundances. TEP: transparent exopolymer particle, n: sample size, -: not applicable

\begin{tabular}{|c|c|c|c|c|c|c|c|c|c|c|c|}
\hline \multirow{2}{*}{ Lake } & \multirow{2}{*}{$\begin{array}{l}\text { Bacterial community } \\
\text { component }\end{array}$} & \multicolumn{5}{|c|}{ Abundance $\left(\times 10^{5}\right.$ cells $\left.\mathrm{ml}^{-1}\right)$} & \multirow{2}{*}{$\begin{array}{c}\text { Mean \% of total } \\
\text { suspended bacteria }\end{array}$} & \multicolumn{2}{|c|}{ Time effect } & \multicolumn{2}{|c|}{ Lake effect } \\
\hline & & $\mathrm{n}$ & Mean & $\mathrm{SD}$ & Min & Max & & $F$ & $\mathrm{p}$ & $F$ & $\mathrm{p}$ \\
\hline \multirow[t]{4}{*}{ All } & TEP-attached bacteria & 26 & 7.25 & 3.60 & 1.57 & 15.0 & 9.55 & 1.08 & 0.424 & 0.128 & 0.881 \\
\hline & Free-living bacteria & 26 & 10.5 & 6.29 & 2.52 & 27.5 & 13.9 & 2.56 & 0.0556 & 5.58 & 0.0154 \\
\hline & Other-attached bacteria & 26 & 62.5 & 26.3 & 13.4 & 145 & 76.5 & 3.17 & 0.0258 & 3.42 & 0.0596 \\
\hline & Total suspended bacteria & 27 & 82.6 & 31.1 & 30.2 & 168 & - & 2.20 & 0.0858 & 3.16 & 0.0700 \\
\hline \multirow[t]{4}{*}{129} & TEP-attached bacteria & 9 & 7.59 & 3.63 & 3.69 & 14.4 & 8.70 & - & - & - & - \\
\hline & Free-living bacteria & 9 & 8.59 & 4.06 & 2.52 & 14.6 & 9.99 & - & - & - & - \\
\hline & Other-attached bacteria & 9 & 74.2 & 28.3 & 49.9 & 145 & 81.3 & - & - & - & - \\
\hline & Total suspended bacteria & 9 & 90.3 & 29.9 & 68.2 & 168 & - & - & - & - & - \\
\hline \multirow[t]{4}{*}{56} & TEP-attached bacteria & 8 & 7.46 & 3.57 & 3.65 & 15.0 & 9.16 & - & - & - & - \\
\hline & Free-living bacteria & 8 & 15.3 & 7.76 & 6.38 & 27.5 & 17.9 & - & - & - & - \\
\hline & Other-attached bacteria & 8 & 62.8 & 15.6 & 41.5 & 88.6 & 73.0 & - & - & - & - \\
\hline & Total suspended bacteria & 9 & 92.1 & 25.1 & 68.7 & 143.3 & - & - & - & - & - \\
\hline \multirow[t]{4}{*}{520} & TEP-attached bacteria & 9 & 6.73 & 3.97 & 1.57 & 12.7 & 10.8 & - & - & - & - \\
\hline & Free-living bacteria & 9 & 8.09 & 4.53 & 3.64 & 15.6 & 14.3 & - & - & - & - \\
\hline & Other-attached bacteria & 9 & 50.7 & 28.9 & 13.4 & 92.0 & 74.9 & - & - & - & - \\
\hline & Total suspended bacteria & 9 & 65.5 & 33.4 & 30.2 & 119 & - & - & - & - & - \\
\hline
\end{tabular}

Lake $520 \quad$ Lake $56 \triangle \quad$ Lake $129 \bigcirc$

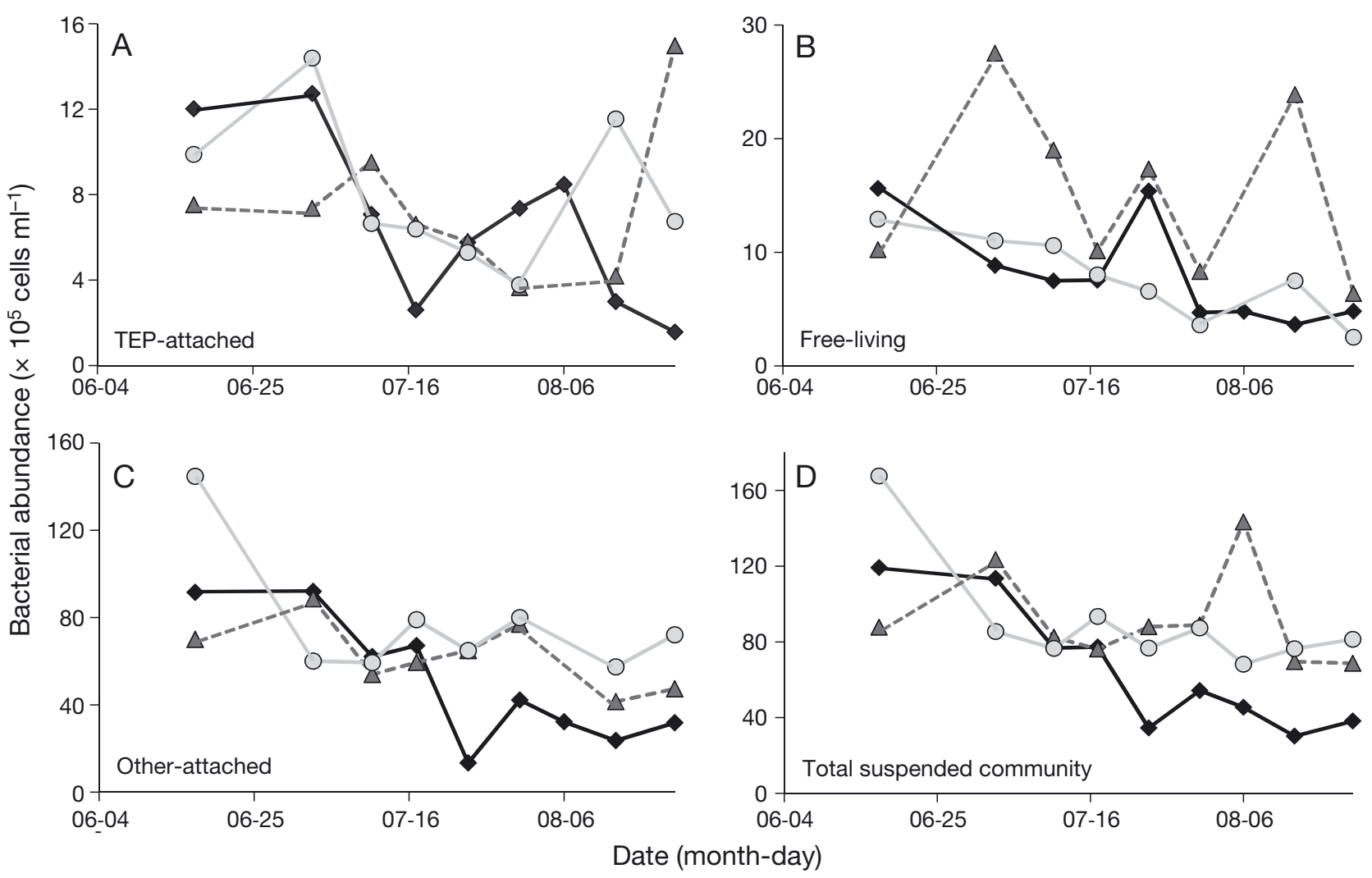

Fig. 2. Seasonal patterns of bacterial abundances for (A) transparent exopolymer particle (TEP)-attached, (B) free-living, (C) other-attached bacteria, and (D) the total suspended community in Lakes 520, 56, and 129 during the open-water period in 2006 
Table 2. Coefficients of determination for relationships between abundances of transparent exopolymer particle (TEP)-attached, free-living, other-attached, and total suspended bacteria versus pertinent environmental variables in Lakes 520, 56, 129, and all lakes combined. The + or - sign indicates whether the relationship is direct or inverse. Alpha significance levels are shown as ${ }^{*}=0.05,{ }^{* *}=0.01,{ }^{* * *}=0.001$. CDOM: chromophoric dissolved organic matter, DOC: dissolved organic carbon, Mono: total dissolved monosaccharides, POC: particulate organic carbon, Poly: total dissolved polysaccharides, TDCHO: total dissolved carbohydrates, TEP-C: TEP carbon concentration, TEP-v: volume-based TEP concentration, TSS: total suspended solids, blank cells: no significant relationship

\begin{tabular}{|c|c|c|c|c|c|c|c|c|c|c|c|}
\hline \multirow[t]{2}{*}{ Variable } & \multicolumn{3}{|c|}{ TEP-attached bacteria } & \multicolumn{3}{|c|}{ Free-living bacteria } & \multicolumn{2}{|c|}{ Other-attached bacteria } & \multicolumn{3}{|c|}{ Total suspended bacteria } \\
\hline & 520 & $56 \quad 129$ & All & 520 & $56 \quad 129$ & All & $520 \quad 56$ & 129 & 520 & $56 \quad 129$ & All \\
\hline TEP-v & $+0.55^{*}$ & & $+0.20^{*}$ & & $+0.48^{*}$ & & $+0.57^{*}$ & $+0.51^{* * *}$ & $+0.61^{*}$ & & $0.39^{* * *}$ \\
\hline DOC & & & & $-0.75^{* *}$ & & $+0.21^{*}$ & & & $-0.49^{*}$ & & \\
\hline TDCHO & & & & $-0.51^{*}$ & & & & & & $-0.52^{*}$ & \\
\hline Mono & & & & & & & & & & & \\
\hline Poly & & & & & & & $-0.45^{*}$ & & $-0.55^{*}$ & $-0.64^{*}$ & \\
\hline CDOM & $+0.53^{*}$ & & & & $+0.77^{* *}$ & & $+0.81^{* * *}$ & $+0.40^{* * *}$ & $+0.88^{* * *}$ & & $+0.26^{* *}$ \\
\hline Chl a & & & & & & & $-0.49^{*}$ & & $-0.56^{*}$ & & \\
\hline TSS & & & & & $+0.70^{*}$ & & & $+0.28^{* *}$ & & & $+0.27^{* *}$ \\
\hline POC & & & & & $+0.56^{*}$ & & $+0.60^{*}$ & & $+0.66^{*}$ & & \\
\hline $\begin{array}{l}\text { TEP-C } \\
\text { pH }\end{array}$ & $+0.81^{* * *}$ & $+0.63^{* *}$ & $+0.51^{* * *}$ & & $+0.67^{* *}$ & & $+0.56^{*}$ & $+0.40^{* * *}$ & $+0.66^{* *}$ & & $+0.36^{* * *}$ \\
\hline
\end{tabular}

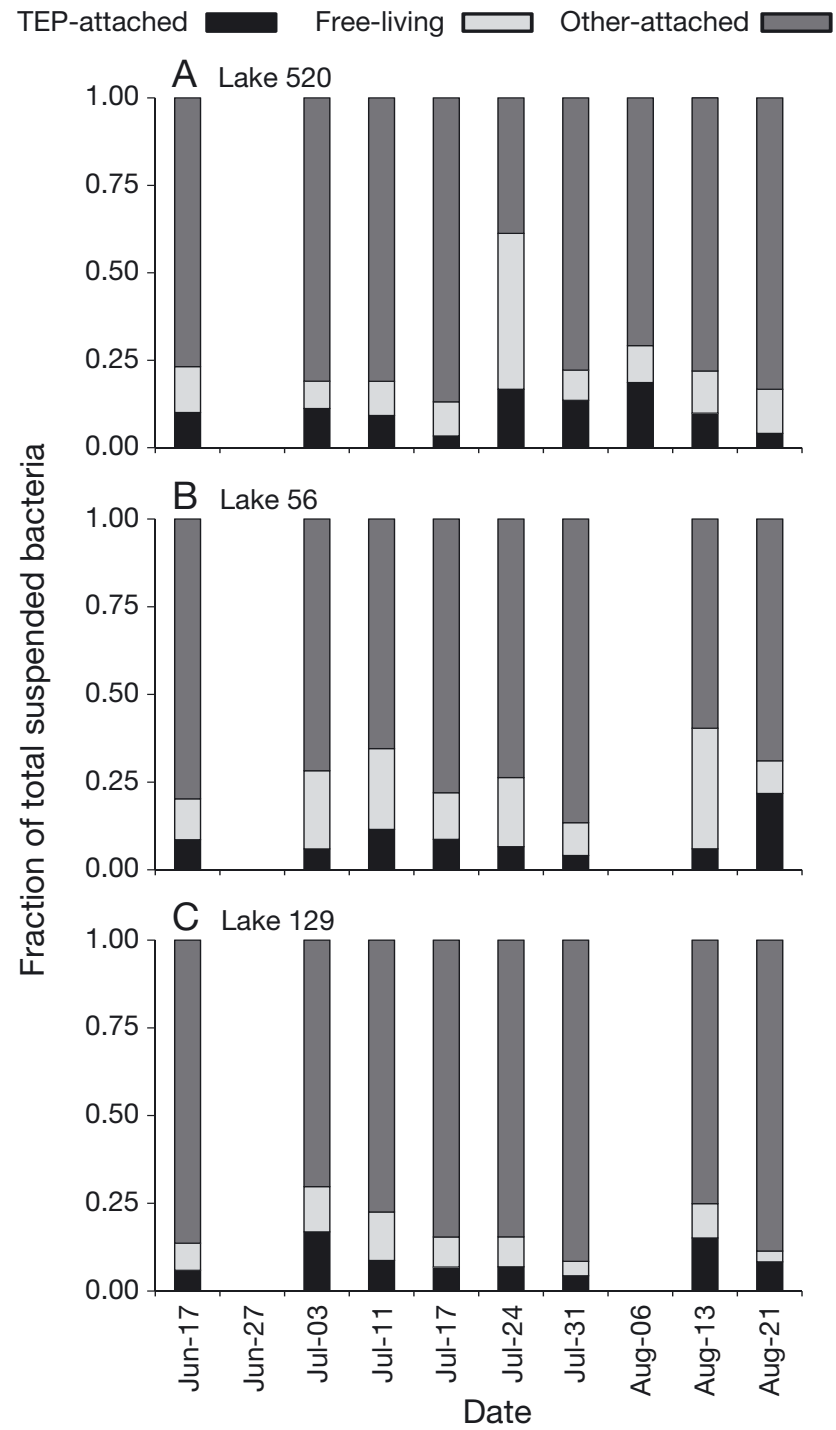

to decline over the summer. TEP-attached bacteria almost always represented the smallest fraction of total suspended bacteria (Fig. 3), with an overall mean of $9.55 \%$ (Table 1). Considering all lakes together, abundance of TEP-attached bacteria was directly related to TEP- $v$, and particularly TEP-C (Fig. 4A). TEP-attached bacteria abundance was also related to CDOM in Lake 520 (Fig. 4C).

\section{Free-living bacteria}

Enumerated abundances of free-living bacteria ranged from $2.52 \times 10^{5}$ to $27.5 \times 10^{5}$ cells ml $^{-1}$, with a mean of $10.5 \times 10^{5} \pm 6.29 \times 10^{5}$ cells ml $^{-1}$ (Table 1 ). In Lakes 129 and 520 (Fig. 2B), abundances gradually declined over the season, with a midsummer spike in Lake 520. In Lake 56, week to week abundances fluctuated substantially. Differences in abundance over time were borderline significant $(F=2.56, \mathrm{p}=$ 0.056, $\mathrm{df}=8$ ), and differences among the lakes were strongly significant $(F=5.58, \mathrm{p}=0.015, \mathrm{df}=2)$ (Table 1). Free-living bacteria represented an overall mean of $13.9 \%$ of total suspended bacteria in the 3 lakes combined (Table 1). Considering all lakes together, abundance of free-living bacteria was directly related to DOC concentrations (Fig. 5D). In Lake 129, abundance was directly related to TEP-C, POC, CDOM, and TSS (Fig. 5A-C,E), but not to

Fig. 3. Fraction of total suspended bacteria contributed by transparent exopolymer particle (TEP)-attached, free-living, and other-attached bacteria in Lakes (A) 520, (B) 56, and (C) 129 during the open-water period in 2006 


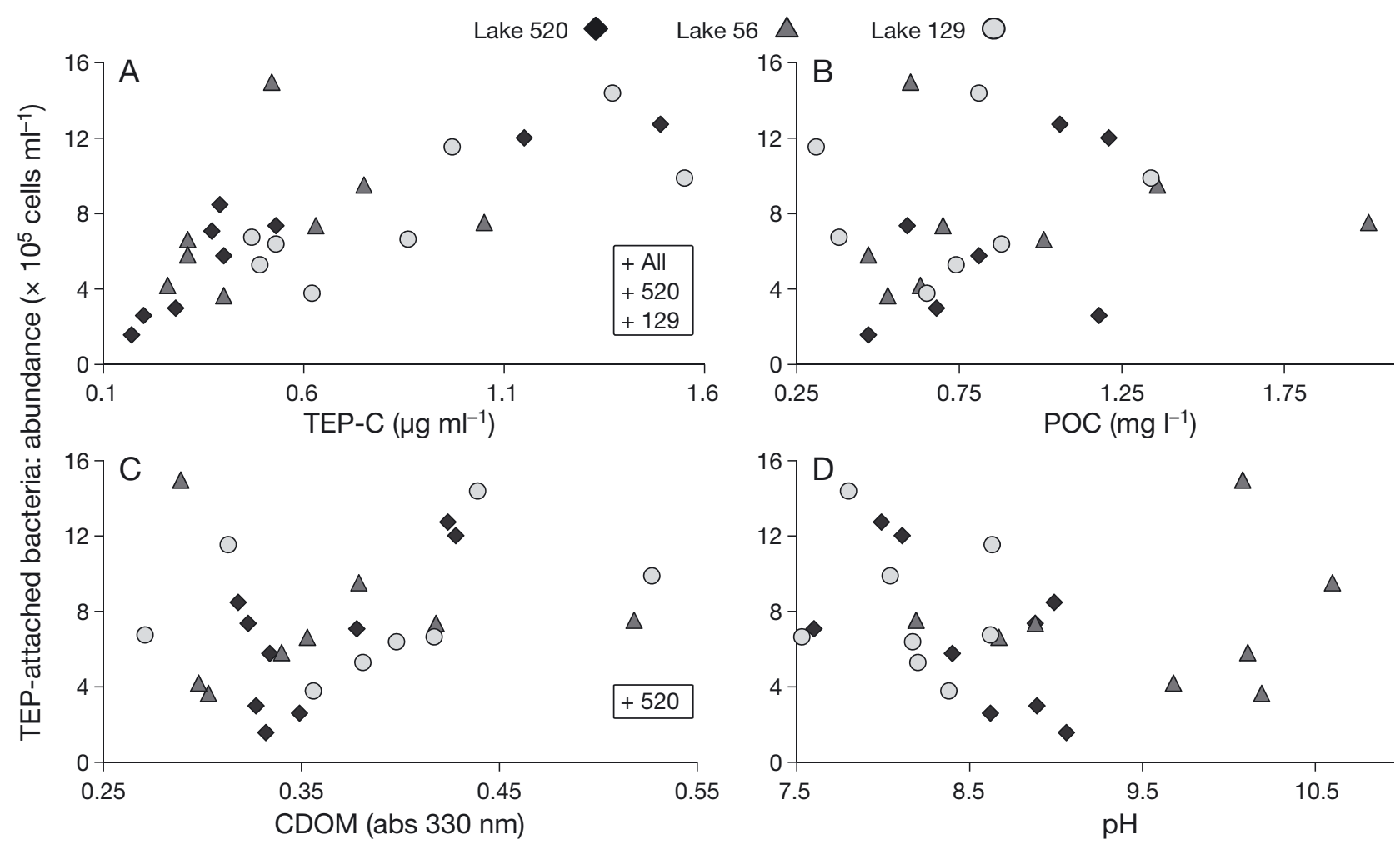

Fig. 4. Abundance of transparent exopolymer particle (TEP)-attached bacteria versus measures of (A) TEP-C, (B) POC, (C) CDOM, and (D) pH during the open-water period in 2006. Data points are coded to separate relationships among Lakes 520, 56, and 129. Significant direct (+) relationships are annotated, as applicable, in the panels for individual and all lakes (see Table 2 for abbreviations and more details)

DOC. In Lake 520, abundance was inversely related to DOC and TDCHO (Fig. 5D,F).

\section{Other-attached bacteria}

In Lake 129, inferred abundance of other-attached bacteria was initially high, then stabilized near the mean as the summer progressed. In Lake 520, abundances declined through the summer, whereas abundances in Lake 56 fluctuated around the mean (Fig. 2C). Differences in abundance over time were significant $(F=3.17, \mathrm{p}=0.026, \mathrm{df}=8)$, and among the lakes were marginally significant $(F=3.42, \mathrm{p}=0.060$, $\mathrm{df}=2$ ) (Table 1). Other-attached bacteria represented an overall mean of $76.5 \%$ of total suspended bacteria in the 3 lakes combined (Table 1), and consequently had a seasonal pattern quite similar to total suspended bacteria. Considering all lakes together, abundance was directly related to TEP-V, TEP-C, CDOM, and TSS (Fig. 6A,C,E). In Lake 520, otherattached bacteria were related directly to $\mathrm{CDOM}$, POC, TEP-v, and TEP-C (Fig. 6A-C), and were inversely related to chl $a$ and polysaccharide concentration (Fig. 6D,F).

\section{Bacterial colonization density on TEP particles}

Bacterial densities on TEP particles ranged from 0.220 to 0.387 cells $\mu^{-2}$ in the smallest size interval (mean ESD: $3 \mu \mathrm{m}$ ), and 0.054 to 0.082 cells $\mu^{-2}$ in the largest size interval (mean ESD: $48 \mu m_{i}$ Fig. 7 , Table 3). Density differences over time were significant only in the intermediate size classes, 12 and $24 \mu \mathrm{m} \mathrm{ESD,} \mathrm{whereas} \mathrm{differences} \mathrm{among} \mathrm{the} \mathrm{lakes}$ were significant in all size classes (Fig. 8, Table 3). Using the ESD $12 \mu \mathrm{m}$ size class as an example, bacterial densities started off equivalent and at minimum values in all lakes on the first sampling date (June 17) shortly after river flooding. Thereafter, bacterial densities on TEP particles in both Lakes 129 and 56 progressively increased over the summer, whereas in Lake 520, densities were variable after an initial increase. Among the lakes, TEP particles in Lake 56 had bacterial densities that were substantially and equivalently higher across all TEP size classes than in Lake 129, with virtually identical slopes for the 2 log-log relationships (Fig. 7, Table 3). By contrast, the log-log slope for Lake 520 was steeper, as a consequence of higher bacterial densities in the smallest size class, but lower densities for the largest size class. 

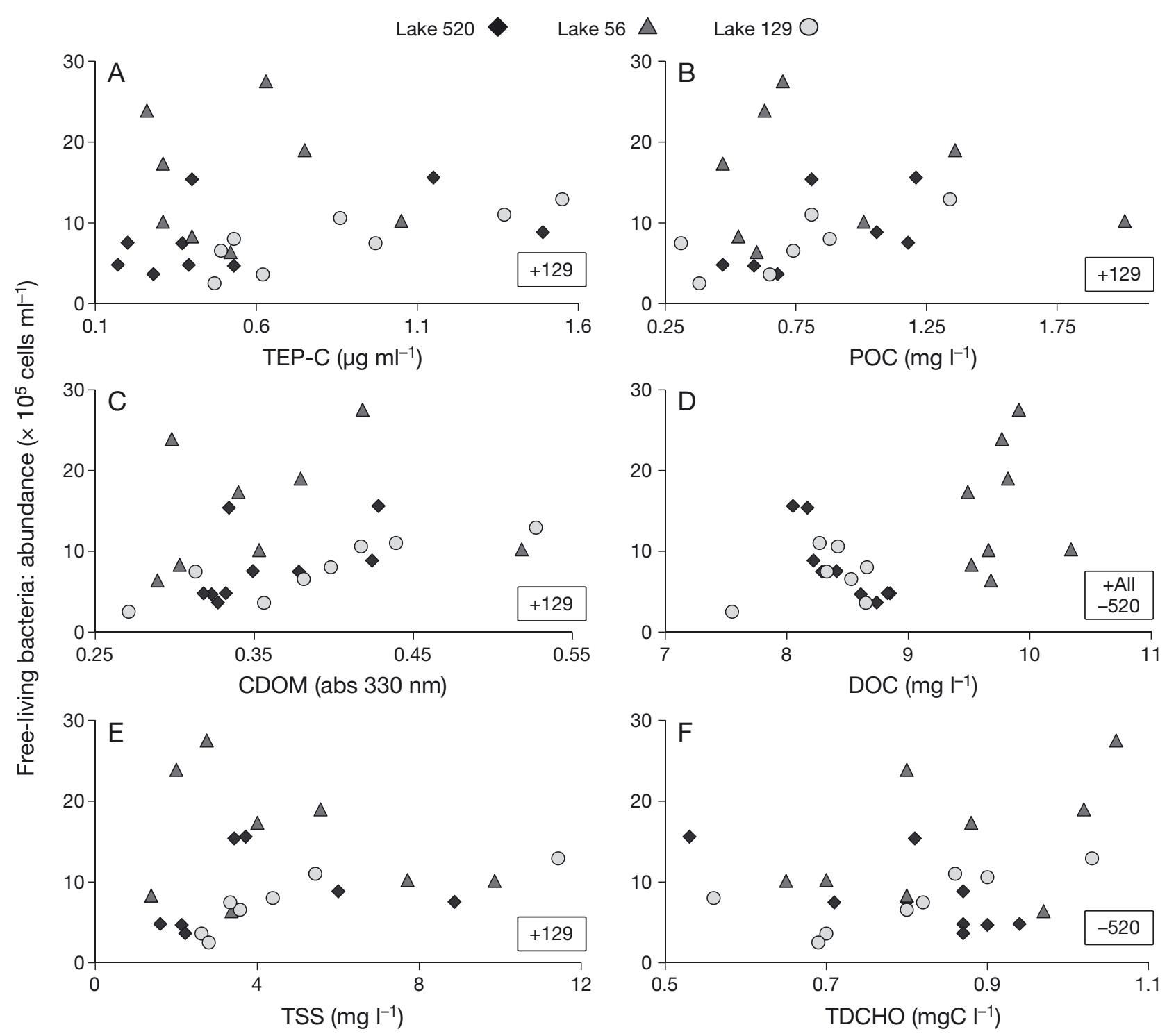

Fig. 5. Abundance of free-living bacteria versus measures of (A) TEP-C, (B) POC, (C) CDOM, (D) DOC, (E) TSS, and (F) TDCHO during the open-water period in 2006. Data points are coded to separate relationships among Lakes 520, 56, and 129. Significant direct (+) and inverse (-) relationships are annotated on each panel for individual and all lakes (see Table 2 for abbreviations and more details)

Bacterial densities on TEP particles were related to a variety of variables (Table 4, Fig. 9), with some variation among the differing size classes. Density on the $12 \mu \mathrm{m}(\mathrm{ESD})$ class was related to more variables than densities on the other size classes. The $12 \mu \mathrm{m}$ class was also likely the best representative of the overall TEP mass in the lakes, given that the average $b$ coefficients (see Eq. 1) ranged from 2.6 to 2.8 among the lakes, indicating a modest bias (3.0 indicating equal contributions from all classes) towards larger particles contributing proportionally more TEP mass than the smaller particles. Considering all lakes together, bacterial density was directly related only to polysaccharide concentrations and, most strikingly, to pH (Fig. 9I,J), but was inversely related to TEP-C, POC, CDOM, and chl a (Fig. 9A-C,G). In Lake 520, bacterial density was directly related only to monosaccharide concentrations (Fig. 9H). In Lake 56, bacterial density was directly related only to polysaccharide concentrations (Fig. 9J), but was inversely related to TEP-C (and TEP-v, not shown), POC, CDOM, and DOC (Fig. 9A-D). In Lake 129, bacterial density was not directly related to any of the measures, but was inversely related to POC, CDOM, TSS, TDCHO, chl $a$, and polysaccharides (Fig. 9B, C,E-G,J). 

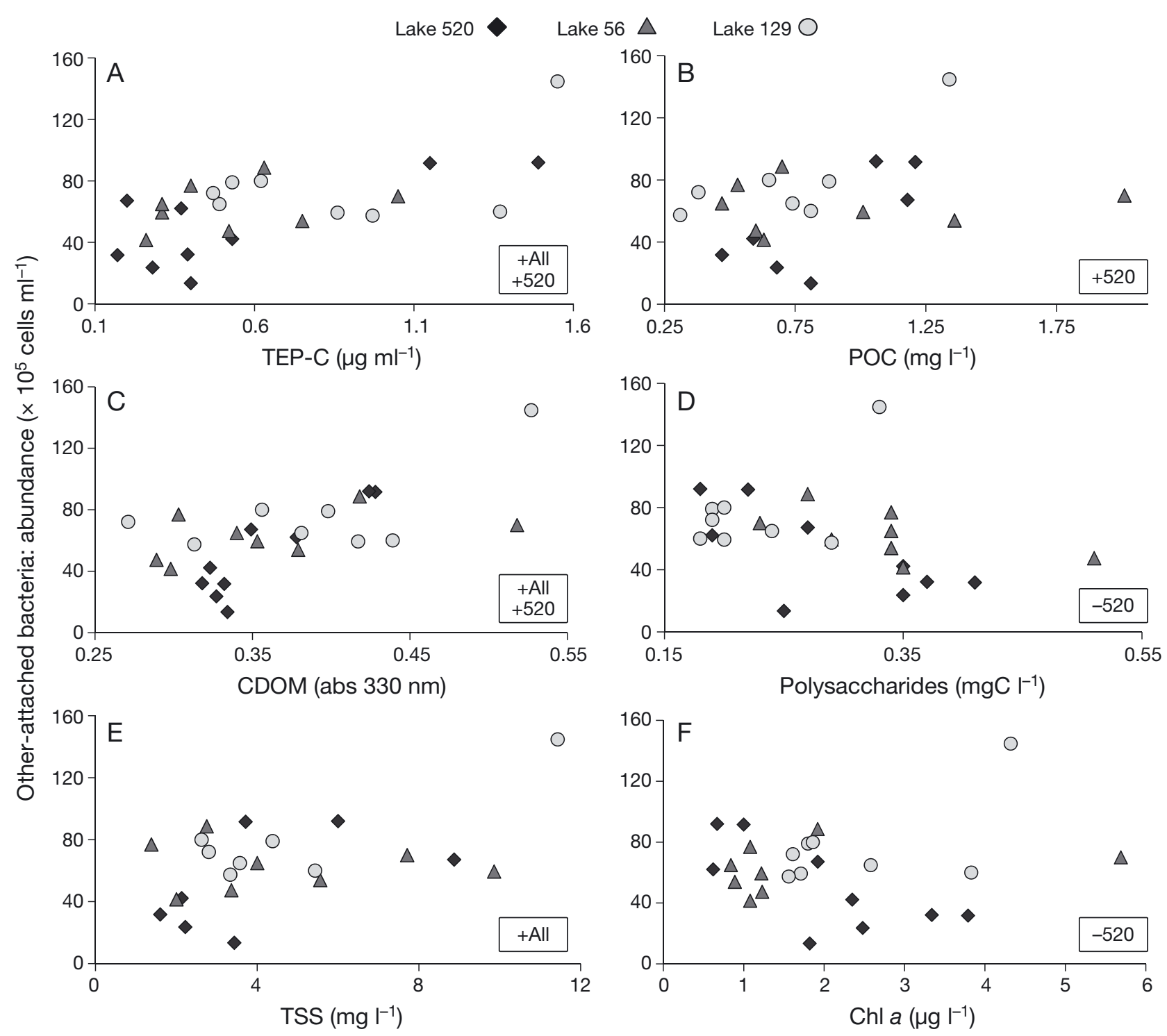

Fig. 6. Abundance of other-attached bacteria versus measures of (A) TEP-C, (B) POC, (C) CDOM, (D) polysaccharides, (E) TSS, and $(F)$ chl a during the open-water period in 2006. Data points are coded to separate relationships among Lakes 520,56, and 129. Significant direct (+) and inverse (-) relationships are annotated on each panel for individual and all lakes (see Table 2 for abbreviations and more details)

\section{DISCUSSION}

\section{Bacterial abundances}

Abundances of total suspended bacteria in these floodplain lakes were higher than generally reported in arctic lake ecosystems, with maximum abundances in the range found in eutrophic systems (Sommaruga \& Robarts 1997). Studies of Toolik Lake, Alaska have consistently yielded bacterial abundances in the range of $1 \times 10^{5}$ to $20 \times 10^{5} \mathrm{cells} \mathrm{ml}^{-1}$ (Hobbie et al. 1983, O'Brien et al. 1992), which are comparable to abundances reported in other arctic lakes (Bertilsson et al. 2003). Prior studies in the Mackenzie Delta have reported either lower (Spears \& Lesack 2006) or similar (Febria 2005) abundances compared to other arctic lakes. We attribute these differences to differing and improved methodology. Both Spears \& Lesack (2006) and Febria (2005) used a $1.2 \mu \mathrm{m}(\mathrm{GF} / \mathrm{C})$ pre-filtration step to focus on the free-living bacterial community. Febria (2005) also used a surfactant treatment (TWEEN 80) to disperse cells adsorbed to particles passing through the prefiltration. Our present method follows protocols from the Toolik Lake lab (J. Hobbie pers. comm.), and employs both a surfactant and sonication to ensure a 


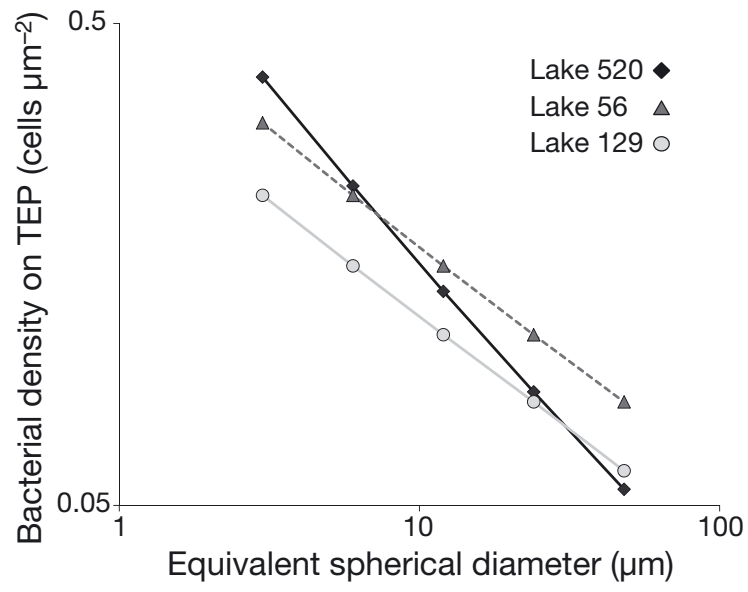

Fig. 7. Mean bacterial density on transparent exopolymer particles (TEP) versus mean size classes of the particles (expressed as equivalent spherical diameter) among Lakes 520, 56, and 129. Both axes are log scale

more complete dispersal of cells prior to enumeration. This is especially important when suspended particle levels are high, as is often the case in delta lakes.

Planktonic bacterial production and abundances typically increase with planktonic primary production and chl a across a wide range of aquatic ecosystems (Cole et al. 1988), but this was not observed in our study system (Spears \& Lesack 2006, Tank 2009), including the 3 lakes in our present study. Exceptions to this pattern have included ecosystems with other significant carbon sources, such as macrophytes, sediment re-suspension, and allochthonous inputs (Findlay et al. 1991), and our results fit this pattern. When our 3 study lakes are considered together, total suspended bacteria were most strongly related to TSS and CDOM, suggesting a link to flood-driven inputs of river water and allochthonous terrestrial carbon (Gareis 2007, Tank 2009). Lack of a statistical relationship between total suspended bacteria and POC when data from all lakes was combined was surprising, although there was a significant relationship with POC in Lake 520.

\section{Partitioning of the bacterial community}

Our interpretation of free-living versus particleattached bacteria follows the model of Miki \& Yamamura (2005), which distinguishes between POCspecialist bacteria, free-living DOC specialists, and generalist bacteria that can utilize either DOC or POC as substrate. Both POC specialists and generalists that colonize POC are envisioned as becoming free-living following metabolic breakdown and hydrolysis of

Table 3. Descriptive statistics for bacterial density on transparent exopolymer particles (TEP) among the differing size classes of particles (expressed as equivalent spherical diameter, ESD) for Lakes 129, 56, 520, and all lakes combined. Includes randomized block ANOVA results for potential time effect and lake effect on observed densities. n: sample size, -: not applicable

\begin{tabular}{|c|c|c|c|c|c|c|c|c|c|c|}
\hline \multirow{2}{*}{ Lake } & \multirow{2}{*}{$\begin{array}{l}\text { Mean ESD } \\
\text { of TEP }(\mu \mathrm{m})\end{array}$} & \multicolumn{5}{|c|}{ Bacterial density on TEP (cells $\mu^{-2}$ ) } & \multicolumn{2}{|c|}{ Time effect } & \multicolumn{2}{|c|}{ Lake effect } \\
\hline & & $\mathrm{n}$ & Mean & $\mathrm{SD}$ & Min & Max & $F$ & $\mathrm{p}$ & $F$ & $\mathrm{p}$ \\
\hline \multirow[t]{5}{*}{ All } & 3 & 26 & 0.306 & 0.132 & 0.148 & 0.677 & 1.03 & 0.456 & 4.79 & 0.0246 \\
\hline & 6 & 26 & 0.202 & 0.064 & 0.107 & 0.355 & 1.67 & 0.187 & 5.62 & 0.0150 \\
\hline & 12 & 26 & 0.136 & 0.035 & 0.073 & 0.208 & 2.95 & 0.0338 & 7.87 & 0.0046 \\
\hline & 24 & 26 & 0.093 & 0.025 & 0.049 & 0.136 & 2.72 & 0.0455 & 8.48 & 0.0034 \\
\hline & 48 & 26 & 0.064 & 0.021 & 0.031 & 0.106 & 1.48 & 0.246 & 6.63 & 0.0087 \\
\hline \multirow[t]{5}{*}{129} & 3 & 9 & 0.220 & 0.044 & 0.166 & 0.307 & - & - & - & - \\
\hline & 6 & 9 & 0.157 & 0.026 & 0.110 & 0.188 & - & - & - & - \\
\hline & 12 & 9 & 0.113 & 0.020 & 0.073 & 0.143 & - & - & - & - \\
\hline & 24 & 9 & 0.082 & 0.019 & 0.049 & 0.111 & - & - & - & - \\
\hline & 48 & 9 & 0.059 & 0.018 & 0.032 & 0.086 & - & - & - & - \\
\hline \multirow[t]{5}{*}{56} & 3 & 8 & 0.311 & 0.115 & 0.148 & 0.488 & - & - & - & - \\
\hline & 6 & 8 & 0.220 & 0.067 & 0.107 & 0.318 & - & - & - & - \\
\hline & 12 & 8 & 0.157 & 0.040 & 0.077 & 0.208 & - & - & - & - \\
\hline & 24 & 8 & 0.113 & 0.026 & 0.055 & 0.136 & - & - & - & - \\
\hline & 48 & 8 & 0.082 & 0.020 & 0.040 & 0.106 & - & - & - & - \\
\hline \multirow[t]{5}{*}{520} & 3 & 9 & 0.387 & 0.160 & 0.153 & 0.677 & - & - & - & - \\
\hline & 6 & 9 & 0.230 & 0.070 & 0.111 & 0.355 & - & - & - & - \\
\hline & 12 & 9 & 0.139 & 0.032 & 0.081 & 0.186 & - & - & - & - \\
\hline & 24 & 9 & 0.086 & 0.019 & 0.058 & 0.117 & - & - & - & - \\
\hline & 48 & 9 & 0.054 & 0.015 & 0.031 & 0.078 & - & - & - & - \\
\hline
\end{tabular}




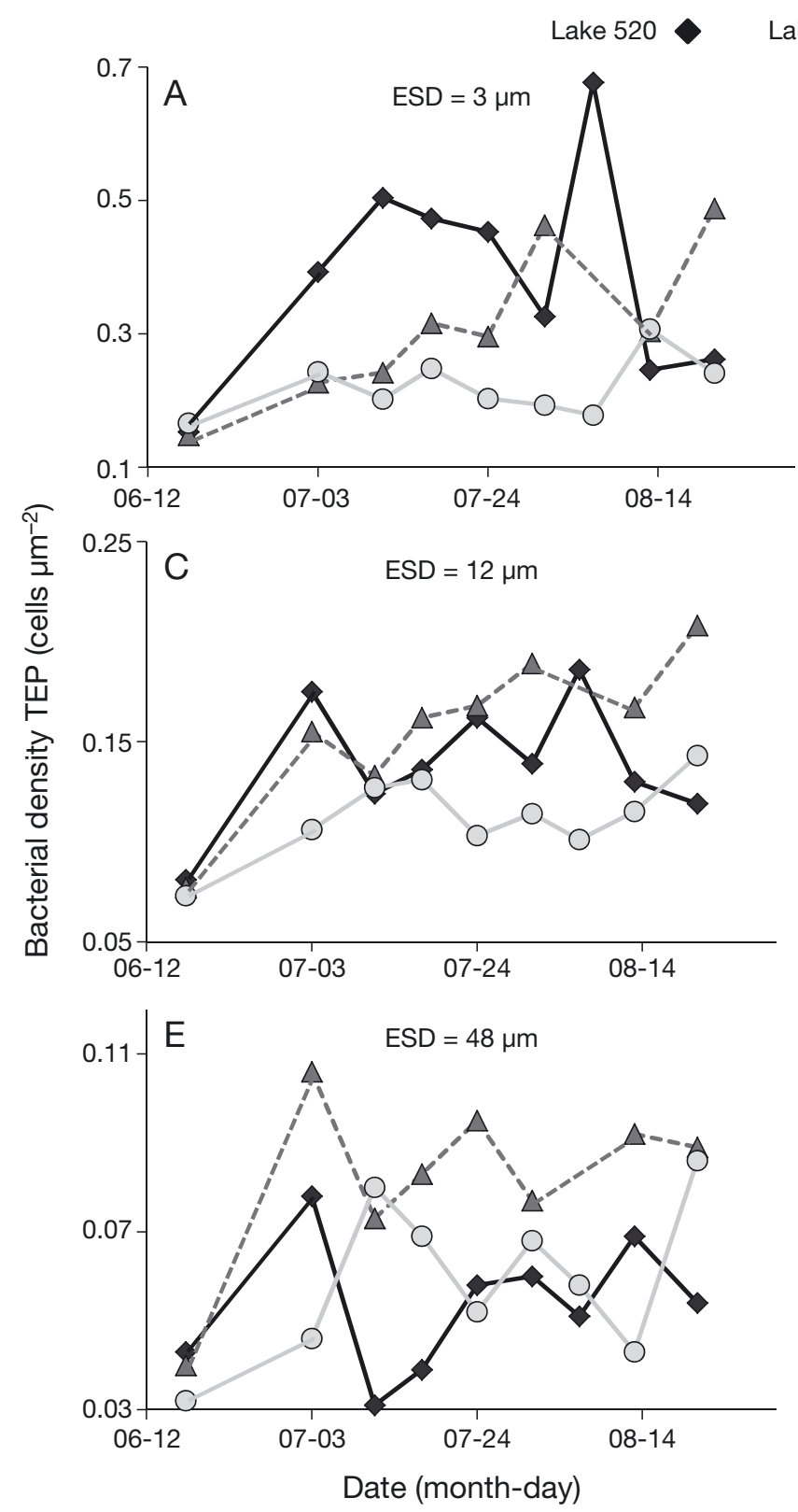

POC and are available to colonize new particles. Thus, our measures of 'free-living' bacterial abundance are interpreted as including both free-living specialists plus additional bacteria that may act as particle colonists. Although our study was not designed to identify and/or enumerate cells as specialists or generalists, simply being aware that these differing classes exist is important for interpreting our results.

\section{TEP-attached bacteria}

We expected that TEP-attached bacteria would represent a significant portion of the total suspended

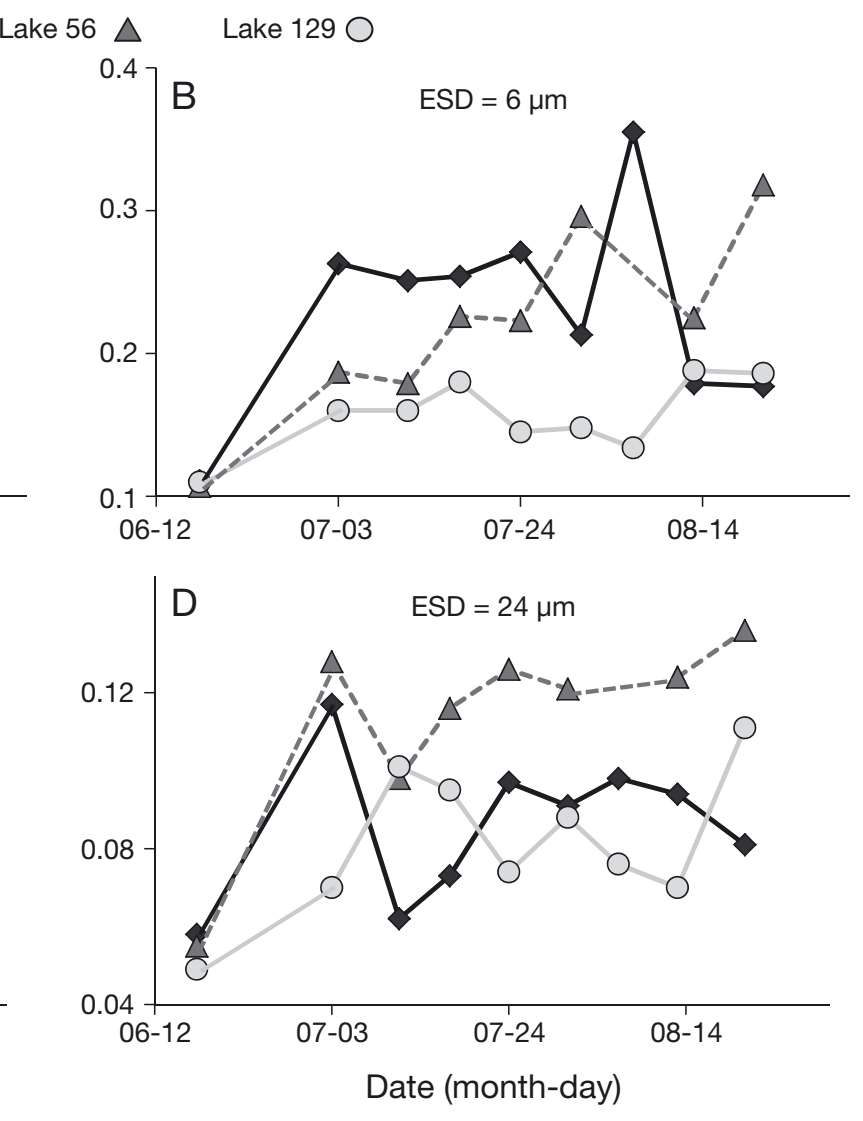

Fig. 8. Seasonal patterns of bacterial density on transparent exopolymer particles (TEP) among differing size classes of particles (expressed as equivalent spherical diameter, ESD, of $3,6,12,24$, and $48 \mu \mathrm{m}$ ) among Lakes 520, 56, and 129 during the open-water period in 2006

bacterial community and would be more abundant in lakes with higher TEP abundance. We also expected that TEP abundance would be highest in lakes with shorter river-connection times because their higher levels of autotrophic productivity would yield higher levels of TEP precursors than in lakes with longer river-connection times. Our finding that TEP-attached bacteria represented $\sim 10 \%$ of total suspended bacteria overall in our 3 study lakes is similar to values found in both marine (Passow 2002 and references therein) and freshwater ecosystems (Worm \& Søndergaard 1998, Carrias et al. 2002). We did indeed detect an overall statistically significant relationship of increasing abundances of TEP-attached bacteria 
Lake 520 Lake $56 \Delta \quad$ Lake 1290
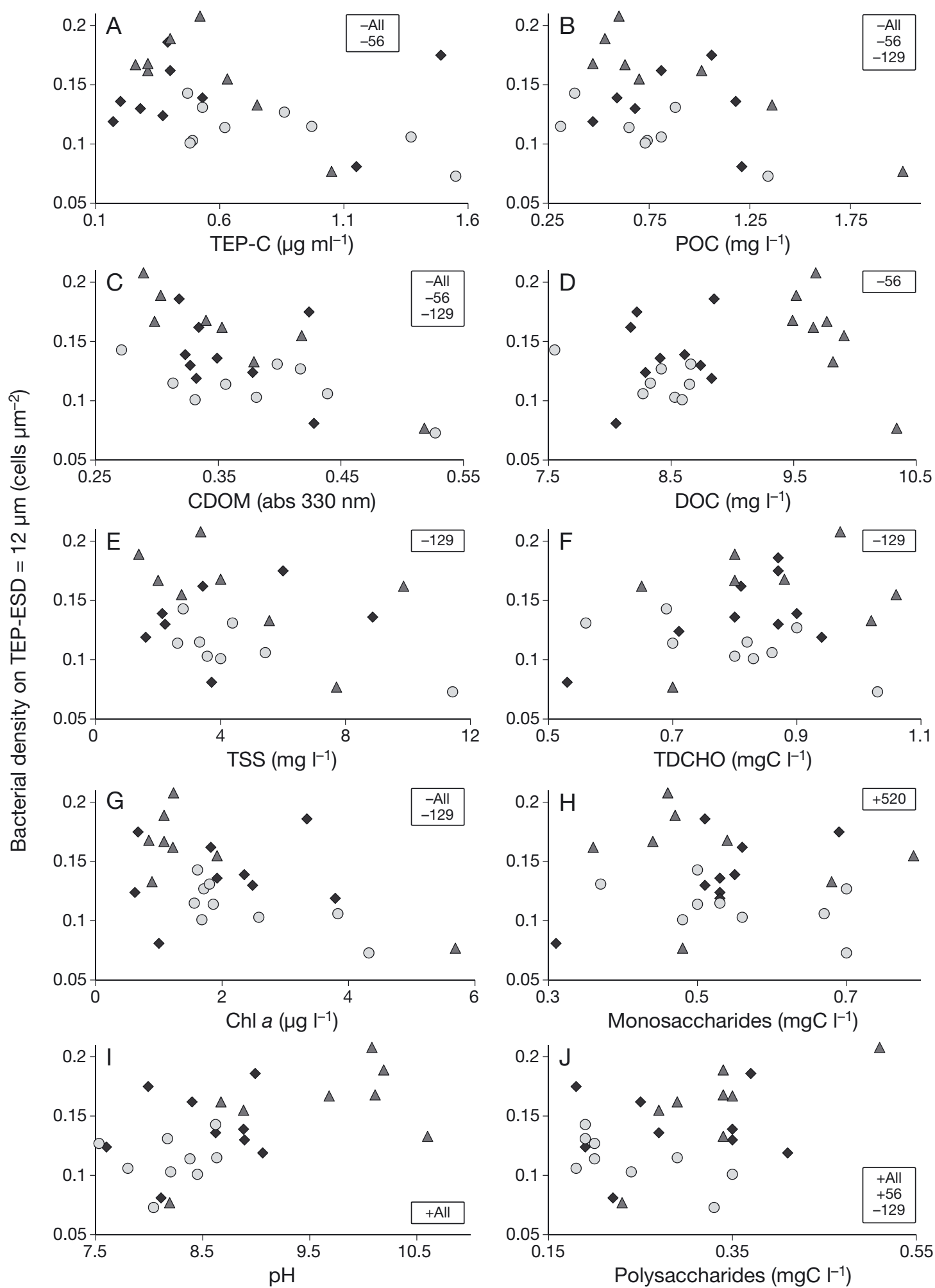

Fig. 9. Bacterial density on a representative size class (equivalent spherical diameter, ESD, of $12 \mu \mathrm{m}$ ) of transparent exopolymer particles (TEP) versus measures of (A) TEP-C, (B) POC, (C) CDOM, (D) DOC, (E) TSS, (F) TDCHO, (G) chl a, (H) monosaccharides, (I) $\mathrm{pH}$, and (J) polysaccharides during the open-water period in 2006. Data points are coded to separate relationships among Lakes 520, 56, and 129. Significant direct (+) and inverse (-) relationships are annotated on each panel for individual and all lakes (see Table 2 for abbreviations and Table 4 for more details) 
Table 4. Coefficients of determination for relationships between bacterial density (cells $\mu^{-2}$ ) on differing size classes (equivalent spherical diameter) of transparent exopolymer particles (TEP) versus pertinent environmental variables in Lakes 520,56, 129, and all lakes combined. The + or - sign indicates whether the relationship is direct or inverse. Alpha significance levels are shown as ${ }^{*}=0.05,{ }^{* *}=0.01,{ }^{* * *}=0.001$. Blank cells: no significant relationship. See Table 2 for abbreviations

\begin{tabular}{|c|c|c|c|c|c|}
\hline Variable & Size $(\mu \mathrm{m})$ & Lake 520 & Lake 56 & Lake 129 & All lakes \\
\hline \multirow[t]{5}{*}{ TEP-v } & 3 & & & & \\
\hline & 6 & & & & \\
\hline & 12 & & $-0.56^{*}$ & $-0.49^{*}$ & \\
\hline & 24 & & $-0.71^{* *}$ & & \\
\hline & 48 & & $-0.65^{*}$ & & \\
\hline \multirow[t]{5}{*}{ TEP-C } & 3 & & & & \\
\hline & 6 & & & & $-0.18^{*}$ \\
\hline & 12 & & $-0.60^{*}$ & & $-0.20^{*}$ \\
\hline & 24 & & $-0.65^{*}$ & $-0.47^{*}$ & \\
\hline & 48 & & $-0.51^{*}$ & $-0.47^{*}$ & \\
\hline \multirow{5}{*}{ Chl a } & 3 & & & & \\
\hline & 6 & & & & \\
\hline & 12 & & & $-0.56^{*}$ & $-0.25^{* *}$ \\
\hline & 24 & & & $-0.54^{*}$ & $-0.29^{* *}$ \\
\hline & 48 & & & $-0.48^{*}$ & $-0.23^{*}$ \\
\hline \multirow[t]{5}{*}{ TSS } & 3 & & & & \\
\hline & 6 & & & & \\
\hline & 12 & & & $-0.59^{*}$ & \\
\hline & 24 & & & $-0.53^{*}$ & \\
\hline & 48 & & & & \\
\hline \multirow[t]{5}{*}{ POC } & 3 & & & & \\
\hline & 6 & & $-0.63^{*}$ & $-0.60^{*}$ & \\
\hline & 12 & & $-0.83^{* *}$ & $-0.52^{*}$ & $-0.21^{*}$ \\
\hline & 24 & & $-0.92^{* * *}$ & & $-0.22^{*}$ \\
\hline & 48 & & $-0.76^{* *}$ & & $-0.19^{*}$ \\
\hline \multirow[t]{5}{*}{ DOC } & 3 & & $-0.53^{*}$ & & \\
\hline & 6 & & $-0.64^{*}$ & & \\
\hline & 12 & & $-0.73^{* *}$ & & \\
\hline & 24 & & $-0.66^{*}$ & & \\
\hline & 48 & & & & $+0.17^{*}$ \\
\hline \multirow[t]{5}{*}{ TDCHO } & 3 & & & & \\
\hline & 6 & & & & \\
\hline & 12 & & & $-0.54^{*}$ & \\
\hline & 24 & $+0.48^{*}$ & & & \\
\hline & 48 & & & & \\
\hline \multirow[t]{5}{*}{ Poly } & 3 & & $+0.64^{*}$ & & \\
\hline & 6 & & $+0.66^{*}$ & & \\
\hline & 12 & & $+0.60^{*}$ & $-0.47^{*}$ & $+0.15^{*}$ \\
\hline & 24 & & & & \\
\hline & 48 & & & & \\
\hline \multirow[t]{5}{*}{ Mono } & 3 & & & & \\
\hline & 6 & & & & \\
\hline & 12 & $+0.54^{*}$ & & & \\
\hline & 24 & $+0.56^{*}$ & & & \\
\hline & 48 & & & & \\
\hline \multirow{5}{*}{ CDOM } & 3 & & $-0.71^{* *}$ & & $-0.22^{*}$ \\
\hline & 6 & & $-0.81^{* *}$ & & $-0.33^{* *}$ \\
\hline & 12 & & $-0.85^{* * *}$ & $-0.45^{*}$ & $-0.39^{* * *}$ \\
\hline & 24 & & $-0.70^{* *}$ & & $-0.29^{* *}$ \\
\hline & 48 & & & & \\
\hline \multirow[t]{5}{*}{$\mathrm{pH}$} & 3 & & & & \\
\hline & 6 & & & & $+0.17^{*}$ \\
\hline & 12 & & & & $+0.33^{* *}$ \\
\hline & 24 & & & & $+0.36^{* *}$ \\
\hline & 48 & & & & $+0.27^{* *}$ \\
\hline
\end{tabular}

with increasing TEP-C during our open-water observations (Fig. 4A). However, the open-water average abundance of TEP-attached bacteria was nearly identical in Lakes 129 and 56 (Table 1), despite TEP-C concentrations being $~ 60 \%$ higher in Lake 129 than in 56 (Figs. 4A \& 9A). Moreover, TEP-C was higher in the lake with the longest river connection time (Lake 129) (see Chateauvert et al. 2012), opposite to our expectation.

\section{Free-living bacteria}

We expected that free-living bacteria would be more abundant in lakes with higher concentrations of DOM substrate. Overall, that was indeed the case (Fig. 5D). When considering the lakes separately, however, the only significant relationship with DOC was in Lake 520, where it was inverse, as was a relationship with TDCHO (Fig. 5F). On the other hand, free-living bacteria in Lake 129 were directly related to our 3 measures of particle abundance (TEP-C, POC, TSS; Fig. 5A,B,E), and most strongly related to CDOM (Fig. 5C), but not DOC. We interpret these patterns in Lake 129 as a signal that CDOM, originating from the river, supports free-living bacteria (DOC specialists and generalists) via release of biolabile DOM during CDOM photobleaching (Febria 2005, Spears \& Lesack 2006). Some of the free-living community in Lake 129 may also be POC specialists released from the various particulates. The result for Lakes 520 and 56 may seem counterintuitive, but is consistent with our other findings in these lakes. Based on stable isotopes and other tracer techniques, Tank et al. (2011) found that in lakes most disconnected from the river (e.g. Lakes 520 and 56), there appeared to be high yields of labile DOM derived from autochthonous production of macrophytes. However, such DOM was rapidly con- 
sumed by bacteria rather than accumulating in the lake, and thus it contributed only $\sim 10 \%$ of the measured lake DOM concentration. The remaining DOC in the lake water appeared to be more recalcitrant, derived from a combination of riverine and local allochthonous inputs, and not well related to in situ bacterial production.

\section{Other-attached bacteria}

We expected that other-attached bacteria would be the predominant component of the bacterial community only in lakes with longer river-connection times and the associated higher levels of TSS, POC, and CDOM. Instead, other-attached bacteria strongly dominated the bacterial community in all 3 lakes, regardless of their river-to-lake connectivity (Fig. 3). Abundance of other-attached bacteria did decline later in the open-water period when TSS decreased. However, even as the lakes became disconnected, suspended sediments settled, and autotrophic production strengthened, other-attached bacteria continued to be the numerically dominant fraction of the suspended bacterial community. Other-attached bacteria were statistically related to TSS, CDOM, and TEP-C overall (Fig. 6A,C,E), but with the exception of Lake 520, not to POC (Fig. 6B). We interpret the lack of an overall relationship with POC as a consequence of a shift in particle quality from the most river-influenced to the least river-influenced lake. Non-TEP particles in Lake 129 are richer in inorganic particles and terrestrial organic detritus (Marsh et al. 1999, Squires \& Lesack 2003), and would enter the lake pre-colonized by bacteria. By contrast, Lake 520 is rich in autochthonous detritus derived from its considerable macrophyte production (Squires et al. 2009), which is a higher-quality substrate, but it has to be colonized by bacteria in situ after it is produced. The presence of high-quality macrophyte detritus in suspension may also potentially explain why otherattached bacteria dominate the overall suspended bacterial community, even in the lakes with low riverine influence.

The overall relationship between other-attached bacteria and TEP-C was unexpected (Fig. 6A), but it may simply be a consequence of the higher average TEP-C in the lake with stronger river influence and higher TSS and CDOM. Alternatively, this could indicate some of the other-attached bacteria were actually TEP-encased. Whereas we enumerated TEP-attached bacteria directly, TEP-encased bacteria can be difficult to enumerate due to difficulties focusing through TEP particles under the microscope. However, even if as many as half of the TEPattached bacteria were not enumerated because they were TEP-encased, this would lead to only a modest reduction in the true proportion of other-attached bacteria.

Our finding that an average of $86 \%$ of the total suspended bacteria in these lakes consists of particleattached bacteria (TEP-attached + other-attached bacteria) is high compared to other findings in the literature. Percentages this high are generally associated with rivers and estuaries, which typically range between 14 and 90\% (Zimmermann-Timm 2002). While lakes often have lower proportions of attached bacteria (in the range of 5 to $30 \%$; Grossart et al. 1998, Wu et al. 2007), some shallow lakes with suspended sediments or those experiencing phytoplankton blooms can be as high as 52\% (Wu et al. 2007 ) or even $80 \%$ (Worm et al. 2001). However, differences in methods for enumerating attached bacteria make direct comparisons problematic. Some investigations (e.g. Wu et al. 2007, the present study) have determined particle-attached bacteria by the difference between samples prepared with and without surfactant plus sonication, whereas others have used size-fractionated filtration techniques (e.g. $>10 \mu \mathrm{m}$; Worm et al. 2001) coupled with sonication to separate particle-attached and free-living bacteria. One study (Grossart et al. 1998) directly sampled and sonicated particles $>3 \mathrm{~mm}$. Few investigations in lakes have enumerated the TEP-attached component of particle-attached bacteria. In cases where sizefractionated filtration was not used, the transparent nature of TEP would lead to an underestimation of attached bacteria. Whereas size-fractionated filtration may capture most of the TEP-attached component, the exact amount would depend on the filter size. Standardization of techniques for determining particle-attached bacterial cells would improve our understanding of these communities.

\section{Bacterial density on TEP particles}

It has been well established that larger TEP particles generally have more bacteria attached to them, but smaller TEP are more densely colonized (Passow \& Alldredge 1994, Mari \& Kiørboe 1996, Carrias et al. 2002). Our results overall (Fig. 7) are consistent with this. This basic pattern may be a result of TEP not being spherical and having a fractal relationship between surface area and particle volume (Mari \& Kiørboe 1996). Our estimates of bacterial densities on 
TEP are within the range reported for marine ecosystems (Passow 2002 and references therein), and are similar to those reported by Carrias et al. (2002) for oligomesotrophic and eutrophic lakes.

Bacterial abundance may not necessarily be stimulated by the formation of TEP per se (Passow \& Alldredge 1994). Hence, after accounting for the particle-size effect and confirming that particle size distributions did not appreciably differ between the lakes (average $b$ coefficients ranging from only 2.6 to 2.8 ), differing bacterial densities on TEP may be due to differences in the age or abundance of TEP particles (Schuster \& Herndl 1995). We thus expected that free-living bacterial cells (POC specialists and generalists) would colonize TEP in proportion to their abundance, resulting in the highest densities of TEPattached bacteria where (assuming similar TEP levels) the pool of free-living bacteria was highest. On the other hand, we expected TEP formation would be highest where autochthonous DOC was highest, which would also coincide with where free-living bacteria were highest. We thus expected that in lakes with strong river influence, bacterial densities on TEP might be similar to lakes with little river influence because, despite lower abundances of freeliving bacteria, TEP levels would also be lower in the river-influenced lakes. Instead, we found that the lake with low riverine influence (Lake 56) had bacterial densities that were significantly higher across all TEP size classes than the lake with strong riverine influence (Lake 129). This could be a consequence of free-living bacteria being nearly twice as abundant in Lake 56 as in Lake 129, but TEP-C being 60\% greater in Lake 129.

Furthermore, bacterial densities on TEP were equal in all 3 lakes immediately after the spring flood (June 17), and this date generally had the lowest values during our study period (Fig. 8). At this time of year, TEP would likely have formed from similar riverine water and have followed a similar formation mechanism in all lakes. TEP-C was also at its seasonal peak level at this time. Following this date, TEP-C declined in all lakes, except on July 3 in Lake 520 (Chateauvert et al. 2012), while bacterial densities on TEP generally increased. The above pattern could indicate that there was greater overall particle area (i.e. both TEP and non-TEP) earlier in the season available for potential bacterial colonizers. Alternatively, TEP derived from river water might be of lower quality for bacteria than TEP derived from autochthonous DOC later in the summer. Of these 2 possibilities, differences in colonizable particle area seems the more likely explanation, given that aver- age bacterial density on TEP in Lake 56 was $45 \%$ higher than in Lake 129, but corresponding TEP-C was $60 \%$ higher in Lake 129 than in Lake 56 over the study period. Moreover, this is also consistent with bacterial densities on TEP being inversely related (statistically significant) to organic particulates (chl $a_{\text {, }}$ POC, and TEP-C; Fig. 9).

We have no direct measure of TEP quality among the lakes; however, there was a striking direct relationship between bacterial density on TEP and $\mathrm{pH}$ (Fig. 9I). The $\mathrm{pH}$ values reflect $\mathrm{pCO}_{2}$ levels in the lake water and are directly related to photosynthetic rates of the macrophyte communities in these lakes (Tank et al. 2009a,b). Although based on only a few observations where $\mathrm{pH}$ was $>9.5$, TEP-attached bacterial abundance and its density on TEP both seemed to be increasing within this high $\mathrm{pH}$ range (Figs. 4D \& 9I). While it is possible that this may result from more abundant free-living bacteria available to colonize the TEP in lakes with less river influence (Lake 56), it is also possible that the TEP derived from the high autotrophic production may be of higher quality and having a growth-stimulating effect on the particles themselves. TEP may also represent a more important substratum during times of hydrologic isolation due to the potential for scavenging colloids and amino acids that may accumulate in the water during such periods (Decho 1990), and the potential for the inclusion of small amounts of higher-quality macrophyte detritus within TEP particles. The complex nature and dynamics of DOC in the Mackenzie Delta lakes (Tank et al. 2011) may affect TEP precursors and TEP quality in ways we do not yet understand.

\section{Implications for carbon cycling}

Assuming there is little variation in TEP-C content after accounting for its particle size distribution (Mari 1999), our measurements indicate that TEP may exceed $80 \%$ of total POC in the Mackenzie Delta lakes (Chateauvert 2008). In contrast, our bacterial enumerations show that only $11 \%$ of the total attached bacterial community was associated with TEP. The fact that $89 \%$ of the attached bacteria were associated with non-TEP particles raises the question of whether bacteria in these lakes might 'prefer' nonTEP particles. However, TEP-attached bacteria were only $12 \%$ more abundant in Lake 129 than in Lake 520 , despite TEP-C being $60 \%$ higher in Lake 129, whereas other-attached bacteria were $45 \%$ more abundant in Lake 129 than in Lake 520, with TSS 
being only $31 \%$ higher in Lake 129 (POC is equivalent in both lakes, on average). This indicates that bacterial densities on non-TEP particles declined from lakes with strong river influence to lakes with only weak river influence, as densities on TEP particles concomitantly increased. This suggests a possible increasing preference of the bacterial colonizers among the lakes for TEP over other particles, although this does not account for the overall low relative content of TEP-attached bacteria. A more likely possibility is that most of the non-TEP particles entering the lake waters are pre-colonized with bacteria and are not strongly dependent on the free-living community for colonization. The portion of such particles with pre-colonized bacteria would likely decline with weakening river influence. This is also consistent with the absence of any inverse relationships between free-living bacteria and measures of particle abundance.

Another possibility is that the low relative content of TEP-attached bacteria in these lakes may be a result of TEP being rapidly removed via bacterial activity, zooplankton consumption, or sedimentation in comparison with other colonized particles. This would be consistent with the unexpected pattern of lower in situ TEP-C in the lakes with substantially high autotrophic production (Chateauvert et al. 2012). These competing possibilities would yield differing effects on the fate of TEP-C. TEP consumed by bacteria would represent yet another route for DOM processing through the microbial loop in Mackenzie Delta lakes, whereas TEP consumed directly by higher trophic levels would short-circuit the microbial loop and increase the efficiency of carbon transfer between DOM and the classical food web. Alternatively, TEP removed from suspension through sedimentation would increase carbon retention in lakes and, since TEP are characterized by a nitrogen content below the Redfield ratio, TEP sedimentation may result in preferential removal of carbon (Engel \& Passow 2001). All of these considerations indicate that TEP can have important implications for carbon cycling in lakes. Our findings also suggest that an important distinction between marine and at least some freshwater environments may be the sheer abundance of allochthonous particles that enter the system pre-colonized with bacteria.

\section{CONCLUSIONS}

Our results indicate that differing river-to-lake connection times may drive relative abundances of free-living versus particle-attached bacteria in Mackenzie Delta lakes, but not as expected. Abundances of total suspended bacteria were high in all lakes, and particles hosted most of the cells despite high DOC concentrations in the lakes. Free-living bacteria were best related to DOC concentrations among the lakes, but they represented only $14 \%$ of total suspended bacteria. TEP-attached bacteria were best related to measures of TEP mass, but represented only $9.6 \%$ of total suspended bacteria. Other-attached bacteria were most strongly related to CDOM and TSS levels, and represented $76.5 \%$ of total suspended bacteria, a percentage that was relatively unaffected by river-to-lake connection time. Abundances of TEP-attached bacteria also varied little among the lakes, because bacterial densities on TEP particles increased as the abundance of their substrate declined from lakes with strong river influence to the lakes with higher autochthonous DOC and only weak river influence. By contrast, inferred bacterial density on non-TEP particles concomitantly declined over the same gradient, as the abundance of their substrate declined. These differing changes in bacterial density, in combination with the overall high abundance of other-attached bacteria, suggest that colonization of TEP is affected strongly by the mass of particles available for colonization by free-living cells within the lakes, whereas non-TEP particles may mostly be entering the lake waters pre-colonized with bacteria derived from the flooded terrestrial landscape or from benthic macrophyte communities. An important unresolved issue for carbon processing in this important class of lakes is that the average TEP-C levels are substantially lower in the lakes with higher levels of DOC and autochthonous photosynthetic production.

Acknowledgements. We appreciate the assistance provided by Suzanne Tank, Jolie Gareis, Leah Honka, and Emily Hines in the lab and field. Technical and logistical assistance was provided by Sharon Katz and William Hurst and the Inuvik Research Centre/Aurora Research Institute. Financial support was received from the Natural Sciences and Engineering Research Council of Canada (NSERC; Discovery Grant and Northern Research Supplement programs to L.F.W.L.); the Polar Continental Shelf Project (helicopter support to L.F.W.L.); the Northern Scientific Training Program of the Department of Indian and Northern Affairs; Science Horizons Youth Internship program of Environment Canada; and facilities use in Inuvik was subsidized by the Aurora Research Institute. Helpful thesis advice was provided by Leah Bendell-Young (Simon Fraser University). We also thank 3 anonymous reviewers for their helpful comments and suggestions. 


\section{LITERATURE CITED}

Alldredge AL, Passow U, Logan BE (1993) The abundance and significance of a class of large, transparent organic particles in the ocean. Deep-Sea Res I 40:1131-1140

Andres D, Doyle PF (1984) Analysis of breakup and ice jams on the Athabasca River at Fort McMurray, Alberta. Can J Civ Eng 11:444-458

> Azam F (1998) Microbial control of oceanic carbon flux: the plot thickens. Science 280:694-696

Azam F, Malfatti F (2007) Microbial structuring of marine ecosystems. Nat Rev Microbiol 5:782-791

> Bertilsson S, Hansson LA, Graneli W, Philibert A (2003) Size-selective predation on pelagic microorganisms in Arctic freshwaters. J Plankton Res 25:621-631

Brachvogel T, Schweitzer B, Simon M. (2001) Dynamics and bacterial colonization of microaggregates in a large mesotrophic lake. Aquat Microb Ecol 26:23-35

Caron DA, Davis PG, Madin LP, Sieburth JM (1986) Enrichment of microbial populations in macroaggregates (marine snow) from surface waters of the North Atlantic. J Mar Res 44:543-565

> Carrias JF, Serre JP, Sime-Ngando T, Amblard C (2002) Distribution, size, and bacterial colonization of pico- and nano-detrital organic particles (DOP) in two lakes of different trophic status. Limnol Oceanogr 47:1202-1209

Chateauvert CA (2008) Concentration, distribution, and bacterial colonization of transparent exopolymer particles (TEP) among Mackenzie Delta Lakes. MSc thesis, Simon Fraser University, Burnaby

Chateauvert CA, Lesack LFW, Bothwell ML (2012) Abundance and patterns of transparent exopolymer particles (TEP) in arctic floodplain lakes of the Mackenzie River Delta. J Geophys Res Biogeosci 117, G04013, doi: 10.1029/2012JG002132

> Chin WC, Orellana MV, Verdugo P (1998) Spontaneous assembly of marine dissolved organic matter into polymer gels. Nature 391:568-572

Cole JJ, Findlay S, Pace ML (1988) Bacterial production in fresh and saltwater ecosystems: a cross-system overview. Mar Ecol Prog Ser 43:1-10

$>$ Dean WE (1974) Determination of carbonate and organic matter in calcareous sediments and sedimentary rocks by loss on ignition: comparison with other methods. J Sediment Petrol 44:242-248

Decho AW (1990) Microbial exopolymer secretions in ocean environments: their role(s) in food webs and marine processes. Oceanogr Mar Biol Annu Rev 28:73-153

$>$ Delong EF, Franks DG, Alldredge AL (1993) Phylogenetic diversity of aggregate-attached vs free-living marine bacterial assemblages. Limnol Oceanogr 38:924-934

Emmerton CA, Lesack LFW, Marsh P (2007) Lake abundance, potential water storage, and habitat distribution in the Mackenzie River Delta, western Canadian Arctic. Water Resour Res 43:W05419 doi:10.1029/2006WR 005139

Engel A, Passow U (2001) Carbon and nitrogen content of transparent exopolymer particles (TEP) in relation to their Alcian Blue adsorption. Mar Ecol Prog Ser 219:1-10

Febria C (2005) Patterns of hydrogen peroxide among lakes of the Mackenzie Delta and potential effects on bacterial production. MSc thesis, Simon Fraser University, Burnaby

Findlay S, Pace ML, Lints D, Cole JJ, Caraco NF, Peierls B (1991) Weak coupling of bacterial and algal production in a heterotrophic ecosystem: the Hudson River estuary. Limnol Oceanogr 36:268-278

Galand PE, Lovejoy C, Vincent WF (2006) Remarkably diverse and contrasting archaeal communities in a large arctic river and the coastal Arctic Ocean. Aquat Microb Ecol 44:115-126

Gareis JAL (2007) Underwater irradiance attenuation and photobleaching of chromophoric dissolved organic matter in shallow arctic lakes of the Mackenzie Delta. MSc thesis, Simon Fraser University, Burnaby

Gareis J, Lesack L, Bothwell M (2010) Attenuation of in situ UV radiation in Mackenzie Delta lakes with varying dissolved organic matter compositions. Water Resour Res 46:W09516

- Grossart HP, Berman T, Simon M, Pohlmann K (1998) Occurrence and microbial dynamics of macroscopic organic aggregates (lake snow) in Lake Kinneret, Israel, in fall. Aquat Microb Ecol 14:59-67

Hewes CD, Holm-Hansen O (1983) A method for recovering nanoplankton from filters for identification with the microscope: the filter-transfer-freeze (FTF) technique. Limnol Oceanogr 28:389-394

Hobbie JE, Corliss TL, Peterson BJ (1983) Seasonal patterns of bacterial abundance in an Arctic lake. Arct Alp Res 15: 253-259

Kirk J (1994) Light and photosynthesis in aquatic ecosystems, 2nd edn. Cambridge University Press, Cambridge

> Lemarchand C, Jardillier L, Carrias JF, Richardot M, Debroas D, Sime-Ngando T, Amblard C (2006) Community composition and activity of prokaryotes associated to detrital particles in two contrasting lake ecosystems. FEMS Microbiol Ecol 57:442-451

> Lesack L, Marsh P (2007) Lengthening plus shortening of river-to-lake connection times in the Mackenzie River Delta respectively via two global change mechanisms along the arctic coast. Geophys Res Lett 34:L23404, doi:10.1029/2007GL031656

> Lesack L, Marsh P (2010) River-to-lake connectivities, water renewal, and aquatic habitat diversity in the Mackenzie River Delta. Water Resour Res 46:W12504

> Long RA, Azam F (1996) Abundant protein-containing particles in the sea. Aquat Microb Ecol 10:213-221

Mackay JR (1963) The Mackenzie Delta area, NWT, Canada. Can Dep Mines Tech Surv, Geogr Branch Mem No. 8. Dept of Mines and Technical Surveys, Ottawa

Mari X (1999) Carbon content and C:N ratio of transparent exopolymer particles (TEP) produced by bubbling exudates of diatoms. Mar Ecol Prog Ser 183:59-71

Mari X, Kiørboe T (1996) Abundance, size distribution and bacterial colonization of transparent exopolymeric particles (TEP) during spring in the Kattegat. J Plankton Res 18:969-986

Marsh P, Hey M (1989) The flooding hydrology of Mackenzie Delta lakes near Inuvik, N.W.T., Canada. Arctic 42: 41-49

$>$ Marsh P, Lesack LFW (1996) The hydrologic regime of perched lakes in the Mackenzie Delta: potential responses to climate change. Limnol Oceanogr 41:849-856

Marsh P, Lesack LFW, Roberts A (1999) Lake sedimentation in the Mackenzie Delta NWT. Hydrol Proc 13: 2519-2536

Miki T, Yamamura N (2005) Theoretical model of interactions between particle-associated and free-living bacteria to predict functional composition and succession in bacterial communities. Aquat Microb Ecol 39:35-46 
Mostajir B, Dolan JR, Rassoulzadegan F (1995) A simple method for the quantification of a class of labile marine pico- and nano-sized detritus: DAPI Yellow Particles (DYP). Aquat Microb Ecol 9:259-266

> Myklestad SM, Skanoy E, Hestmann S (1997) A sensitive and rapid method for analysis of dissolved mono- and polysaccharides in seawater. Mar Chem 56:279-286

Nusch EA (1980) Comparison of different methods for chlorophyll and phaeopigment determination. Arch Hydrobiol Beih. Ergebn Limnol 14:14-36

O'Brien WJ, Hershey AE, Hobbie JE, Hullar MA and others (1992) Control mechanisms of Arctic lake ecosystems: a limnocorral experiment. Hydrobiologia 240:143-188

Passow U (2002) Transparent exopolymer particles (TEP) in aquatic environments. Prog Oceanogr 55:287-333

Passow U, Alldredge AL (1994) Distribution, size and bacterial colonization of transparent exopolymer particles (TEP) in the ocean. Mar Ecol Prog Ser 113:185-198

Porter KG, Feig YS (1980) The use of DAPI for identifying and counting aquatic microflora. Limnol Oceanogr 25: 943-948

Prowse TD (1986) Ice jam characteristics, Liard-Mackenzie rivers confluence. Can J Civ Eng 13:653-665

Schuster S, Herndl GJ (1995) Formation and significance of transparent exopolymeric particles in the northern Adriatic Sea. Mar Ecol Prog Ser 124:227-236

Simon M, Grossart HP, Schweitzer B, Ploug H (2002) Microbial ecology of organic aggregates in aquatic ecosystems. Aquat Microb Ecol 28:175-211

Sommaruga R, Robarts RD (1997) The significance of autotrophic and heterotrophic picoplankton in hypertrophic ecosystems. FEMS Microbiol Ecol 24:187-200

Spears BM, Lesack LFW (2006) Bacterioplankton production, abundance, and nutrient limitation among lakes of the Mackenzie Delta (western Canadian arctic). Can J Fish Aquat Sci 63:845-857

Squires MM, Lesack LFW (2003) Spatial and temporal patterns of light attenuation among lakes of the Mackenzie Delta. Freshw Biol 48:1-20

Squires M, Lesack L, Hecky R, Guildford S, Ramlal P, Higgins S (2009) Primary production and carbon dioxide metabolic balance of a lake-rich arctic river floodplain: partitioning of phytoplankton, epipelon, macrophyte, and epiphyton production among lakes of the Mackenzie Delta. Ecosystems 12:853-872

Editorial responsibility: Fereidoun Rassoulzadegan, Villefranche-sur-Mer, France
Tank S (2009) Sources and cycling of dissolved organic carbon across a landscape of arctic delta lakes. PhD thesis, Simon Fraser University, Burnaby

$>$ Tank S, Lesack L, Hesslein R (2009a) Northern delta lakes as summertime $\mathrm{CO}_{2}$ absorbers within the Arctic landscape. Ecosystems 12:144-157

> Tank S, Lesack L, McQueen D (2009b) Elevated pH regulates bacterial carbon cycling in lakes with high photosynthetic activity. Ecology 90:1910-1922

> Tank S, Lesack L, Gareis J, Osburn C, Hesslein R (2011) Multiple tracers demonstrate distinct sources of dissolved organic matter to lakes of the Mackenzie Delta, western Canadian Arctic. Limnol Oceanogr 56:1297-1309

Verdugo P, Alldredge AL, Azam F, Kirchman DL, Passow U, Santschi PH (2004) The oceanic gel phase: a bridge in the DOM-POM continuum. Mar Chem 92:67-85

- Welschmeyer NA (1994) Fluorometric analysis of chlorophyll $a$ in the presence of chlorophyll $b$ and pheopigments. Limnol Oceanogr 39:1985-1992

Wetzel RG, Likens GE (2000) Limnological analyses, 3rd edn. Springer, New York, NY

Whitehead RF, de Mora S, Demers S, Gosselin M, Monfort P, Mostajir B (2000) Interactions of ultraviolet-B radiation, mixing, and biological activity on photobleaching of natural chromophoric dissolved organic matter: a mesocosm study. Limnol Oceanogr 45:278-291

> Worm J, Søndergaard M (1998) Alcian blue-stained particles in a eutrophic lake. J Plankton Res 20:179-186

- Worm J, Gustavson K, Garde K, Borch NH, Søndergaard M (2001) Functional similarity of attached and free-living bacteria during freshwater phytoplankton blooms. Aquat Microb Ecol 25:103-111

> Wu QLL, Chen YW, Xu KD, Liu ZW, Hahn MW (2007) Intrahabitat heterogeneity of microbial food web structure under the regime of eutrophication and sediment resuspension in the large subtropical shallow Lake Taihu, China. Hydrobiologia 581:241-254

> Yoon WB, Rosson RA (1990) Improved method of enumeration of attached bacteria for study of fluctuation in the abundance of attached and free-living bacteria in response to diel variation in seawater turbidity. Appl Environ Microbiol 56:595-600

> Zimmermann-Timm H (2002) Characteristics, dynamics and importance of aggregates in rivers - an invited review. Int Rev Hydrobiol 87:197-240

Submitted: March 3, 2010; Accepted: October 17, 2012 Proofs received from author(s): December 11, 2012 